\title{
Lean Management Maturity in the Indian Industry: Results from a Longitudinal Exploratory Study using Exploratory Factor Analysis
}

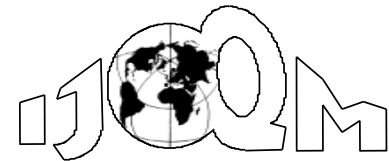

DOI: $10.46970 / 2021.27 .2 .1$

\author{
Rajagopalan Jayaraman \\ SP Jain Institute of Management and Research \\ (jayaraman@spjimr.org)
}

Volume 27, Number 2

June 2021, pp. 81-110

Surveys were conducted between the years 2013 to 2016, in select manufacturing companies, known to practice lean management (LM) in India, called LML (LM Leaders), using the LESAT (Lean Enterprise Self-Assessment Tool) questionnaire, Version 2.0. The objective was to assess the maturity of adoption of $L M$. The results of the longitudinal study indicate that the status of $L M$ in the LML's has improved by about $9 \%$ between the years. Using Exploratory Factor Analysis, we have found that six component factors, into which 21 factors loaded significantly, can explain 59\% of the variation.

Keywords: Lean management (LM), LM Leaders in Indian industry (LMLII), Lean Enterprise Self-Assessment Tool (LESAT), Longitudinal survey, individual period analysis, combined analysis, reverse EFA confirmatory analysis, LM maturity (LMM)

\section{Introduction}

Lean has been practiced in various industrial sectors in India, such as, automotive, pharma, steel plants (e.g., Prashar, 2014, Chowdary and George, 2011, Roy and Guin, 1999). A systematic review of LM in Indian industry by Sangwan et al (2014) indicates that, out of a total of 27 papers published between 1988 and 2012, 19 papers address the application of LM in Indian industry. A survey by Chaple et al., (2014) on Lean literature on Indian industry reports that 106 papers have been published on LM since 1977 till date. However, all of these papers are focused either on a single company (case studies) or sectors of industry and give a snapshot view of LM.

Snapshot studies do not enable a chronological understanding of LM. Also, factors that are either holding back or supporting LM cannot be meaningfully identified by one-time studies. For example, one year, $5 \mathrm{~S}$ may be low, the next year, JIT is not done and the third year, kaizens may have declined. Only longitudinal studies can identify such factors, and their effects on LM. Moreover, longitudinal studies are holistic in approach. They enable a better understanding of the context as well as progress in time.

Sangwan et al., (2014), have done a comprehensive literature survey of the papers published in LM between 1988 and 2012. They have classified papers according to the type of study. They have identified sixteen papers from India, on Indian industry, which are longitudinal studies. However, none of the studies have been classified as 
'exploratory, longitudinal and cross sectional'. In fact, none of the 209 papers are in this Section.

While longitudinal studies have been done in LM, none has been done on LMM on LMLII. We identified this gap and an opportunity to contribute to research. We have chosen LMLII as we wanted to focus our attention on companies who have already attained a certain level of maturity in LM, and we wanted to study LMM. Such a study would be useful not only to LMLII but also to other companies too.

Why study LM in LMLII? The main reason is that LM can lead to quantum jumps in company performance. And such quantum jumps are needed in Indian industry, if India is to emerge as a global economy. Since this is the goal of the Indian government, we decided to find out how ready are the LMLII's to assist the achievement of this goal. Table 1, from the work of Spear and Bowen (1999), is a typical example of the quantum leaps of performance through LM.

Table 1 The Quantum Improvements Possible through Implementation of LM (source: Steven Spear and Kent Bowen, 1999)

\begin{tabular}{|l|c|c|c|c|c|}
\hline \multicolumn{1}{|c|}{ Feature } & $\mathbf{1 9 8 6}$ & $\mathbf{1 9 8 8}$ & $\mathbf{1 9 9 2}$ & $\mathbf{1 9 9 6}$ & $\mathbf{1 9 9 7}$ \\
\hline Styles & 200 & 325 & 670 & 750 & 750 \\
\hline Units per day & 160 & 230 & 360 & 530 & 550 \\
\hline Units per person & 8 & 11 & 13 & 20 & 26 \\
\hline Productivity index & 100 & 138 & 175 & 197 & 208 \\
\hline Finished goods inventory (days) & 30 & 2.5 & 1.8 & 1.5 & 1.5 \\
\hline Number of assembly lines & 2 & 2 & 3 & 3 & 2 \\
\hline
\end{tabular}

More such instances can be found in the book by Womack and Jones (1996). Such quantum jumps in company performance in Indian companies have also been reported by Chowdary and George (2011), Sameh and Tamer (2011), Rajenthirakumar et al (2011), Singh et al (2014 a), Vinodh et al (2010) and Vinodh et al (2015). Bhim Singh, Garg and Sharma (2010), in their study of a company located in northern India and practicing LM, found that reduction in lead time was 83.14 percent, reduction in processing time was 12.62 percent, reduction in work-in-process inventory was 89.47 percent, and reduction in manpower requirement was 30 percent. The rise in productivity per operator was 42.86 percent. Whereas Spear and Bowen and Womack and Jones have done longitudinal tracking of LM performance in companies, the Indian papers have reported snapshot studies. However, both show quantum jumps, both, in the long term and the short term. This is a unique quality of LM.

\subsection{Purpose of the Research}

Fullerton et al., 2014, show that LM has a direct effect on firm performance, both operations and financial. Given the importance of LM, it is imperative that Indian industry takes up LM and adopts its practices. To facilitate these efforts, one must find out the reasons and the factors that enable companies to adopt LM. This paper aims to study the developments in the adoption of LM by large Indian corporates, which have been in the LM movement for many years. We call them as LMLII. By studying the LM practices in the LMLII, we propose to estimate the state of LM maturity, identify the factors which support as well as hold back LM progress and understand the 
underlying causes. And, it is the LMLII's who have the maximum chance of succeeding in making LM happen (see Shah and Ward, 2003 and Ghosh, 2012).

In order to develop the analysis on a firm theoretical footing, we have used the methodology of 'reverse EFA' and 'coupled analysis', which will be explained in detail in the course of the paper.

The remainder of the paper is structured as follows. First, a synopsis of the Lean literature is provided, especially in the context of Indian industry. Next, the research method is discussed, where the LESAT survey is further detailed. The results of the survey and analysis, using the 'reverse EFA' and 'coupled analysis', are discussed in section 4. Lastly, the paper concludes with a summation of the ways in which the analyses and results described can be used in the LMLII to improve LM practices.

\section{LM in Indian Industry}

LM is a collection of principles and practices developed as a part of the Toyota Production System (TPS) (Liker (2014), Hopp and Spearman (2004), Womack et al., (2003, 2007), Spear and Bowen, (1999), Jacquemont (2014) and Amir Abolhassani et al., (2016)). The scope of coverage of LM can be summarized into various application areas, principles and practices (see Table 2).

Table 2 LM Application Areas, Principles and Practices (Source: Author's Summarization of Literature on LM, from Various Books and Papers, including Womack and Jones, 1996, Spear and Bowen, 1999, Imai, 1991, Ishikawa, 1989, Kume, 1993 and Smith, 2000)

\begin{tabular}{|c|l|l|}
\hline Area of application of Lean & \multicolumn{1}{|c|}{ Typical principles and practices } & \multicolumn{1}{c|}{ Typical benefits } \\
\hline & Lead time reduction & Shorter manufacturing cycles \\
& Set up time reduction (SMED) & Smaller batch sizes \\
& Single unit flow & Flexible production \\
& Pull production (or Kanban) & Low inventories \\
& Takt time & Customer satisfaction \\
& Heijunka (or levelled production) & As above \\
& Andon & High quality, consistent \\
& JIT & Low inventories \\
& Reduced materials transport & Less damage and waste \\
& Reduced materials handling & As above \\
& Autonomation (Jidoka) & Relevant automation \\
\hline \multirow{5}{*}{ Logistics } & Milk runs & Faster replenishment \\
& Short lead time & Smaller lot size \\
& Smaller shipments & Lower lead times, flexi \\
& Faster turn around & Speedier dispatch \\
& Use of warehouses & Lower inventory \\
& Cross docking & Accuracy \\
\hline \multirow{5}{*}{ Procurement } & Sensei & Win win \\
& Strategic sourcing & Long term \\
& Co-location & High co-ordination \\
& JIT & Flexibility \\
& Kanban supplies & Low inventories \\
\hline \multirow{2}{*}{ IT companies } & Scrum & Lead time reduction \\
& Bench & Flexible allocation \\
\hline \multirow{5}{*}{ Banking } & Value Stream Mapping & Eliminate waste \\
& Process streamlining & Improve efficiency \\
& Process metrics \& monitoring & Kaizens \\
& Parallel processing & Shorter lead times \\
\hline & Waste reduction & Low prices to customers \\
\hline & & \\
\hline & & \\
& &
\end{tabular}


In India, interest in LM seems to come predominantly from applications in manufacturing, especially in automobile and electronics industry sectors (Chaple et al., 2014). Descriptions of the practices and the results achieved in Indian industry can be found in the works of Gupta and Jain, (2016), Bhamu and Sangwan (2014), Begam et al, (2013), Yadav et al, (2010), Kumar et al, (2013), Seth \& Gupta (2005), Upadhye et al., (2010a and b), Anand and Kodali (2009), Dhandapani et al., (2004), Prashar, (2014), Chowdary and George, (2011), Rajenthirakumar et al., (2011), Roy and Guin, (1999), Singh et al., (2014 a), Vinodh et al., (2015), Damle and Nandurkar, (2011). An illustrative set of achievements through LM in Indian industry, based on the works of some of these authors, is given in Table 3.

Table 3 Key Achievements of LM Applications in Indian Industry

\begin{tabular}{|c|c|c|}
\hline Lean practices & Results Achieved & References \\
\hline $\begin{array}{l}\text { Assembly line } \\
\text { performance improvement } \\
\text { using lean, manufacturer } \\
\text { of steering systems }\end{array}$ & $\begin{array}{l}\text { Distance travelled reduced by } 30 \% \text {, } \\
\text { floor area usage reduced by } 16 \% \text {, } \\
\text { inventory reduced by } 110 \% \text {, removal } \\
\text { of eight machines and redeployment in } \\
\text { another project, defect rate reduced by } \\
32 \%\end{array}$ & Prashar, 2014 \\
\hline $\begin{array}{l}\text { Improvement of } \\
\text { operations in a pharma } \\
\text { company, using lean } \\
\text { methods }\end{array}$ & $\begin{array}{l}\text { NVA time reduced by } 65 \% \text {, total cycle } \\
\text { time reduced by } 65 \%, 50 \% \text { reduction } \\
\text { in workforce, } 85 \% \text { reduction in WIP, } \\
40 \% \text { reduction in floor utilisation and } \\
38 \% \text { reduction in floor space occupied }\end{array}$ & $\begin{array}{l}\text { Chowdary and } \\
\text { George, } 2011\end{array}$ \\
\hline $\begin{array}{l}\text { Paint shop of a } \\
\text { construction company, } \\
\text { using VSM and process } \\
\text { analysis }\end{array}$ & $\begin{array}{l}\text { Masking time reduced by } 55 \% \text {, cost of } \\
\text { the masking process reduced by } 80 \% \text {, } \\
63 \% \text { time saved in the drying process, } \\
45 \% \text { reduction in process lead time, } 29 \\
\% \text { reduction each in WIP and total } \\
\text { cycle time }\end{array}$ & $\begin{array}{l}\text { Rajenthirakumar et } \\
\text { al, } 2011\end{array}$ \\
\hline $\begin{array}{l}\text { Reduction of inventory in } \\
\text { an integrated steel plant, } \\
\text { using JIT to reduce } \\
\text { inventory lead time and } \\
\text { freight consolidation }\end{array}$ & Reduction in freight cost of up to $69 \%$ & $\begin{array}{l}\text { Roy and Guin } \\
\text { (1999) }\end{array}$ \\
\hline $\begin{array}{l}\text { Assembly line operations } \\
\text { in an automobile } \\
\text { company, using VSM } \\
\text { analysis }\end{array}$ & $\begin{array}{l}22 \% \text { improvement in process time, } \\
33.7 \% \text { improvement in production } \\
\text { lead time, } 17.6 \% \text { improvement in the } \\
\text { value-added ratio, } 50 \% \text { reduction in } \\
\text { WIP }\end{array}$ & $\begin{array}{l}\text { Singh et al., (2014 } \\
\text { a) }\end{array}$ \\
\hline $\begin{array}{l}\text { Automotive components } \\
\text { manufacturing company, } \\
\text { VSM and Cpk studies }\end{array}$ & $\begin{array}{l}3.4 \% \text { reduction in NVA activities, } \\
40 \% \text { reduction in production lead } \\
\text { time, } 10 \% \text { increase in OEE }\end{array}$ & $\begin{array}{l}\text { Vinodh et al., } \\
(2015)\end{array}$ \\
\hline $\begin{array}{l}\text { Application of VSM in an } \\
\text { automotive company }\end{array}$ & $\begin{array}{l}65 \% \text { reduction in WIP, } 60 \% \text { reduction } \\
\text { in production lead time, } 90 \% \\
\text { reduction in a work station change } \\
\text { over time, substantial reduction in cost }\end{array}$ & $\begin{array}{l}\text { Damle and } \\
\text { Nandurkar, (2011) }\end{array}$ \\
\hline
\end{tabular}


Ghosh (2012) argues that mainly large enterprises in India respond to Lean surveys and are considerably more active in Lean implementation as compared to the Small to Medium-sized Enterprises (SMEs). Shah and Ward (2003, 2007) have also reached the same conclusion after a study of US companies. A comprehensive study by Krishnan and Parveen (2013) refers to quality management, Just-in-Time (JIT) and human resources tools (e.g., training, small group activities, kaizens) used in Indian industry as a part of LM. The works by Panwar et al., (2015), Thanki and Thakkar (2014), Jasti and Kodali (2014 and 2016), and Mahapatra and Mohanty (2007), Singh (2016), Singh et al., (2016), Yogesh and Prabagaran (2016), Singh et al., (2014 a), Singh et al. (2014 b), Kumar, (2014), Mishrikoti and Puranik, (2011), Gupta and Jain (2013), Chakraborty et al. (2013), Khadse et al. (2013), Kundu and Bairy (2014), Mathew and Jones (2012), Sharma et al. (2015) cover the entire gamut of LM implementation in India. Some of the key conclusions from these works is shown in Table 4 below:

Table 4 Main Findings from Studies in Indian LM

\begin{tabular}{|c|c|}
\hline LM Status in Indian industry & References where the view has been supported \\
\hline $\begin{array}{l}\text { Top management of many Indian } \\
\text { industries has not committed itself } \\
\text { to Lean }\end{array}$ & $\begin{array}{l}\text { Kumar (2014), Priti Khadse et., (2013), Panwar et } \\
\text { al., (2015), Mishrikoti and Puranik (2011), Jasti } \\
\text { and Kodali (2016), Bhim Singh, 2016, Mahapatra } \\
\text { and Mohanty (2007) }\end{array}$ \\
\hline $\begin{array}{l}\text { Knowledge of Lean practices is low } \\
\text { in management and shop floor } \\
\text { employees }\end{array}$ & $\begin{array}{l}\text { Panwar et al., (2015), Chaple et al., (2014), Thanki } \\
\text { and Thakkar (2014), Chakraborty et al., (2013), } \\
\text { Jasti and Kodali (2016), Bhim Singh, } 2016\end{array}$ \\
\hline $\begin{array}{l}\text { Firms consider Lean as a capital- } \\
\text { intensive approach and expensive to } \\
\text { implement }\end{array}$ & $\begin{array}{l}\text { Panwar et al., (2015), Priti Khadse et al (2013), } \\
\text { Chaple et al., (2014), Thanki and Thakkar (2014), } \\
\text { Chakraborty et al., (2013), Jasti and Kodali (2016), } \\
\text { Bhim Singh (2016) }\end{array}$ \\
\hline $\begin{array}{l}\text { Many to most MSME's in India do } \\
\text { not practice Lean }\end{array}$ & $\begin{array}{l}\text { Thanki and Thakkar (2014), Vikram Sharma et al., } \\
\text { 2015, Jasti and Kodali (2016) }\end{array}$ \\
\hline $\begin{array}{l}\text { Systematic studies of Lean } \\
\text { prevalence in Indian industry have } \\
\text { not been undertaken so far }\end{array}$ & $\begin{array}{l}\text { Priti Khadse et al., (2013), Mishrikoti and Puranik } \\
\text { (2011) }\end{array}$ \\
\hline $\begin{array}{l}\text { Lack of understanding of processes/ } \\
\text { awareness of Lean is one of the } \\
\text { main hurdles in lean practice in } \\
\text { Indian industry }\end{array}$ & $\begin{array}{l}\text { Kumar (2014), Priti Khadse et al., (2013), Panwar } \\
\text { et al (2015), Mishrikoti and Puranik (2011), Thanki } \\
\text { and Thakkar (2014), Thanki and Thakkar (2014), } \\
\text { Chakraborty et al., (2013), Bhim Singh, (2016) }\end{array}$ \\
\hline $\begin{array}{l}\text { People are reluctant to make the } \\
\text { changes needed to become Lean } \\
\text { (e.g., organizational resistance, fear } \\
\text { of losing job, etc.) }\end{array}$ & $\begin{array}{l}\text { Panwar et al., (2015), Mathew and Jones (2012), } \\
\text { Vipul Gupta et al., (2013), Priti Khadse et al., } \\
\text { (2013), Panwar et al., (2015), Chaple et al., (2014), } \\
\text { Thanki and Thakkar (2014), Jasti and Kodali } \\
\text { (2016), Bhim Singh (2016) }\end{array}$ \\
\hline $\begin{array}{l}\text { Low levels of education of shop } \\
\text { floor employees and low levels of } \\
\text { empowerment }\end{array}$ & $\begin{array}{l}\text { Farhana et al., (2009), Mathew and Jones (2012), } \\
\text { Mahapatra and Mohanty (2007), Vipul Gupta et al., } \\
\text { (2013), Mishrikoti and Puranik (2011), Chaple et } \\
\text { al., (2014), Chakraborty et al., (2013) }\end{array}$ \\
\hline $\begin{array}{l}\text { Training of employees is difficult in } \\
\text { Indian industry }\end{array}$ & $\begin{array}{l}\text { Panwar et al., (2015), Chaple et al., (2014), Thanki } \\
\text { and Thakkar (2014), Chakraborty et al., (2013), } \\
\text { Jasti and Kodali (2016) }\end{array}$ \\
\hline
\end{tabular}




\subsection{Selection of Questionnaire}

\section{Research Methodology}

Amir Abolhassani et al., (2016) and Jasti and Kodali (2014) tested their questionnaire on participants, and then revised the questions in consultation with academics and industry personnel prior to finalization. On the other hand, Shah and Ward (2003), used a survey questionnaire already prepared by Penton Media and Price Waterhouse Coopers. In fact, they even used the data supplied by Penton. Such a method has the advantages that the preliminary steps, such as, pilot survey, consultations with academics and industry practitioners before the questions are finalized, have been gone through and the questionnaire is 'survey ready'. Hallam and Keating (2014) used the MIT LAI LESAT survey questionnaire for their work. In the present study, we chose the path adopted by Shah and Ward (2003) and Hallam and Keating (2014).

\subsection{Sample Size}

The recommended sample size in literature is 10 per question (or variable, as in our case), or a minimum of 300 . Several websites give formulae for sample size calculation. Van De Geer, 1993, Kalton, 1983, Hedeker et al., 1999, Schlesselmann, 1973, have also made certain recommendations regarding sample sizes, sample data analysis, and so on, the last two specifically on longitudinal sample sizes. According to https://www.surveysystem.com/sscalc.htm\#two, the sample size for our study works out to 678 , with a confidence interval of + or $-3.5 \%$, assuming a population size of 5,000. As per https://sciencing.com/meaning-sample-size-5988804.html, the sample size of 741 is likely to have an error margin of + or $-3.7 \%$. Similarly, using https://www.qualtrics.com/experience-management/research/determine-sample-size/ leads to 536, with the confidence level of $95 \%$, margin of error of + or $-3 \%$. Hence, our sample size of 741 appears to be acceptable, for a longitudinal study.

\subsection{Choice of Instrument for Responses}

The next question is the method to be adopted for gathering the data. We selected one year as the period to conduct the longitudinal study. The study would be conducted by MBA students who would handle the entire process of mailing of the chosen questionnaire, receiving responses, following up wherever and whenever needed. Prior to selecting a questionnaire, we examined a number of LM models. Some of the lean maturity models that we examined include the work by Martichenko (https://cdn2.hubspot.net/hubfs/527773/CTA-The_Lean_Leadership_Maturity_Mode l.pdf? $\mathrm{t}=1519910053011$ ), Nightingale and Mize, 2002, Nesensohn et al., 2014, and, King County Lean Maturity Model (https://Kingcounty.gov). Doolen and Hacker, (2005), in their study of electronics companies in the Pacific Northwest in the USA, have listed several lean assessment models. Wan and Chen, 2008, have developed a lean assessment model for manufacturing companies using Data Envelopment Analysis (DEA). Urban, 2015, has developed a lean maturity self-assessment model based on organizational culture diagnosis. The optimal choice for our work was Nightingale and Mize's work of LESAT. Details of LESAT are available in the Ph D dissertation work of Hallam, 2003.The LESAT model has been developed through contributions and discussions between over one hundred professional managers on both sides of the Atlantic, and tested with over hundreds of professional managers 
working in companies. Its usefulness has been proven. The questionnaire is comprehensive, and manageable. The questionnaire and its interpretation and responding are so very well documented that there is no need for any interviewer to be present when the respondent is filling up the answers.

The Martichenko questionnaire has to be administered only by a consulting agency, and that of King county is highly customised to their requirements - of managing a county in the state of Utah in the USA. The work of Nesensohn et al., is suitable for lean construction work. We found some other models, but all these were rejected because either they were too complicated with too many questions (119 in the case of Sangwa and Sangwan, 2017) or they were customised to suit specific requirements, for example, Mohammad et al., 2015. We looked at the MIT website and found the LAI-LESAT version 2.0. The easy availability of the full version of the survey instrument was also a factor in favour of LESAT. The web-search was done as a part of the development of a blended learning course on 'Lean Management' at a reputed management school in India. Quite apart from the fact that we have chosen to use a method similar to those used in literature, the suitability of the LESAT method (LAI LESAT, 2012; LAI LESAT Facilitators Guide, 2012; LAI LESAT Data Entry File, 2012) for our study was the single biggest factor why it was chosen.

\subsection{Data Collection}

The questionnaire developed by the MIT LAI team, called 'LESAT', version 2.0, was administered by a team of 5 to 6 students per team, 6 to 7 teams per year, in 6 to 7 companies, as a part of the course work for the course "Lean Enterprise" in the oneyear Post Graduate Program of Management in a famous B School. This course has been adapted from the MIT course on "Lean Enterprise", the details of which are available in the MIT website https://ocw.mit.edu/courses/aeronautics-andastronautics/16-852j-integrating-the-lean-enterprise-fall-2005/index.htm. Selecting to use the LESAT survey instrument had the advantage of our students being quite familiar with the objectives and the framework of how the LESAT was developed. This would help them in getting speedy responses. Moreover, the version 2.0 measures LM maturity, appropriate for LML's.

Our students - about 150 of them over five years - knew personnel in the companies - either former colleagues or former students from our institute - who helped them in getting the responses. Responses were received over emails, from respondents who were sent the survey questionnaire over emails. Surveys were conducted in the months of August to October each year. Every company sent 30 responses, except three. Responses were then studied for completeness, and if found incomplete, the concerned respondents were contacted over phone, to get additional data. All the $741(n=741)$ responses were thus complete in all respects and usable

This same methodology has been used by Shahram Taj $(2005,2008)$ and Shahram Taj and Cristian (2011) in their studies of LM in Chinese companies. The Beijing International MBA program, BiMBA, at Peking University provided Shahram Taj with a research grant to conduct a study, while he was teaching in China. Mr. Quarterman Lee, President of Strategos, Inc. gave Shahram Taj permission to use his lean assessment tool. A total of 91 students in full- and part-time programs in two operations management classes were given detailed information about the assessment 
tool and provided with a cover letter explaining the purpose of this research in English and Chinese.

Although not ideal, the respondents and the sample size across the four years varied. This is a characteristic which is often found in longitudinal studies, where companies grow, merge, and vanish, and units and departments (including their employees) consolidate, disintegrate or completely dissolve. As such, there are a vast array of longitudinal studies with changing samples across years (e.g., Giunipero et al., 2005; Leong et al., 2003; Lysonski et al., 2003; Markku et al., 2014, Steffie et al., 2016). In longitudinal studies, due to the long-time gaps between data collection, certain changes may happen in the target population, responders and the questionnaire itself. In our case we used the same survey questions, but the responders were not the same every year. This is the case with the research work done by Lysonski et al., (2003). Leong et al., (2003) have also used a similar method in their research in Australia. The principle that we have applied for our surveys is: the respondents are practitioners of LM in LMLII. Each response, therefore, is to be treated as representing the view of a member of the LMLII community involved in and practicing LM, and not individual companies. Thus, in each year, we have obtained the views from about 150 such representatives. This same logic has been used by Shang and Pheng, (2013), who, in their study, used the responses from professionals from large construction companies in China, as representing the industry as a whole, and not individual companies.

Table 5 Details of Respondents Covered in the LESAT Surveys $(n=741)$

\begin{tabular}{|c|l|l|c|}
\hline $\begin{array}{c}\text { Year of } \\
\text { survey }\end{array}$ & Company Name & Industry Generic Name & $\begin{array}{c}\text { Total number of } \\
\text { respondents }\end{array}$ \\
\hline \multirow{2}{*}{2013} & $\begin{array}{l}\text { Daimler } \\
\text { VRV Pr. Vessels } \\
\text { Maruti } \\
\text { M \& M Auto Div. }\end{array}$ & $\begin{array}{l}\text { Large Auto } \\
\text { Medium Sized } \\
\text { Large Auto } \\
\text { Large Auto }\end{array}$ & 108 \\
\hline \multirow{5}{*}{2014} & Apollo Tyres & Large Auto Tyre & \\
& Ashok Leyland & Large Auto & \\
& Bosch & Large auto component & \\
& Tata Motors & Large Auto & \\
& Toyota Kirloskar & Large Auto \\
& Varroc Lighting & Medium Lighting & \\
& Ford India & Large Auto & \\
\hline \multirow{5}{*}{2015} & Hero Moto Corp & Large Two-Wheeler & \\
& Flipkart & Online Retailer & \\
& John Deere & Large Tractor & \\
& 3M & Large Consumables & \\
& Tata Hitachi & Large Earth Moving & \\
& Tata Motors & Large Auto & \\
& Ashok Leyland & Large Auto & \\
& Schneider Electric & Large Electric & \\
\hline \multirow{5}{*}{2016} & Asian Paints & Large Paints & \\
& Toshiba & Large Battery & \\
& Mondelez & Large Food \& Bev & \\
& M \& M Auto Div. & Large Auto & \\
& SKF & Large Engg & \\
& Maruti & Large Auto & \\
& Bisleri & & \\
\hline
\end{tabular}


The survey consists of 68 questions grouped under three categories. There are, in all, 30 questions in Section I: 'Enterprise Transformation Leadership' (i.e., questions involving directions by the top management of the company, strategic alignment, etc.), 30 in Section II: 'Lifecycle Processes' (i.e., questions involving development of organizational capabilities and performance), and 8 in Section III: 'Enabling Infrastructure' (i.e., questions involving organizational and process enablers ) (see LESAT facilitators guide for a detailed explanation of the questions in each Section). Each question has two responses - a score for the current state and a score for the desired (future) state. The desired (future) state score is a benchmark set by the respondent against which the current state score can be compared. The larger the gap, the larger is the 'catch up' work needed. Respondents are required to indicate the 'level' (scale 1 to 5) for each question, for both 'current state' and 'future state'. Each level is a descriptor, a qualifying statement which provides a choice to the respondent to choose the one statement which suits his opinion the best.

The response scores were tabulated in four excel files, each of which can analyse the data based on embedded macros in the file. For each year, analysis is intended to identify: current state summary, desired state summary, gap summary, Section averages, graphs, SWOT analysis, alignment analysis and dimensional analysis.

In total, 26 Indian companies participated in this study, including 24 large Indian private sector companies, and leaders in their domains and two smaller private sector engineering companies. The company personnel, i.e., the respondents who filled out the survey, were selected from the groups of persons who were working in the area of LM for many years. The data is shown in Table 5.

In all, 741 survey responses were filled out by employees working at various levels in the participating firms. Each year, we selected LMLII's from a set of companies. Respondents varied each year, but the same questions were administered. The respondents were considered as representatives of the community of LM area in the LMLII, and hence no company specific analysis has been attempted. Some companies have been polled more than once in the four years. It was ensured that all the responses were complete in all respects. In all, 68 questions needed two responses per question, for a total of 136. From each company we collected 30 responses, and then combined all the responses for analysis purposes. Respondents were from the middle and senior management, but not from the top management. They were personnel who typically design initiatives for implementation of LM, who gather data, who analyse data for further improvement. Thus, we could get the responses from persons who were at the cutting edge of LM adoption and implementation, and were driving LMM.

\section{Results and Discussion}

The responses from the surveys were studied to find answers to the research questions: RQ1: What is the 'absolute level' (maturity) (scale 1 to 5) of LM in the LMLII between 2013 to 2016? What has been the trend - increase, decrease, steady - in the absolute level of LMLII in the period 2013-2016?

The absolute level will indicate the maturity of deployment of Lean, higher the average absolute level, higher is the maturity, and, consequently, higher the benefits from LM.

RQ2: What are the key factors that can be used to characterize LM in the LMLII? The identification will be based on the 'coupled analysis' and 'reverse EFA' results. 
RQ3: Based on the results, can the set of 68 questions in the LESAT survey be substituted by a smaller set of questions for surveys to be conducted in India on the LMLII?

\subsection{RQ1: Absolute levels, and trends, of LM in LMLII (2013-2016)}

Before analysis, the reliability and internal consistency of data is assessed by calculating the Cronbach Alpha values. Most studies on Lean in Indian industry report Cronbach Alpha values of between 0.7 and 0.95. For example, Singh (2016), Jasti and Kodali (2016) and Sharma and Gupta, (2015), report a Cronbach alpha of >0.94, $>0.70$, and $>0.77$, respectively. Cronbach Alpha values for the dataset of responses for each year was calculated, and were found to be relatively high, showing that the data is reliable and internally consistent (Table 6).

Table 6 Cronbach-alpha Values for different Years

\begin{tabular}{|c|c|c|}
\hline Year & Current State & Desired State \\
\hline 2016 & 0.947 & 0.932 \\
\hline 2015 & 0.970 & 0.967 \\
\hline 2014 & 0.920 & 0.973 \\
\hline 2013 & 0.759 & 0.879 \\
\hline
\end{tabular}

The averages of the responses in each of the three categories of the LESAT, as well as the consolidated (across all categories), were calculated for each year. Thus, for each year, there were eight points, four for the current state and four for the future state scores.

wise and consolidated

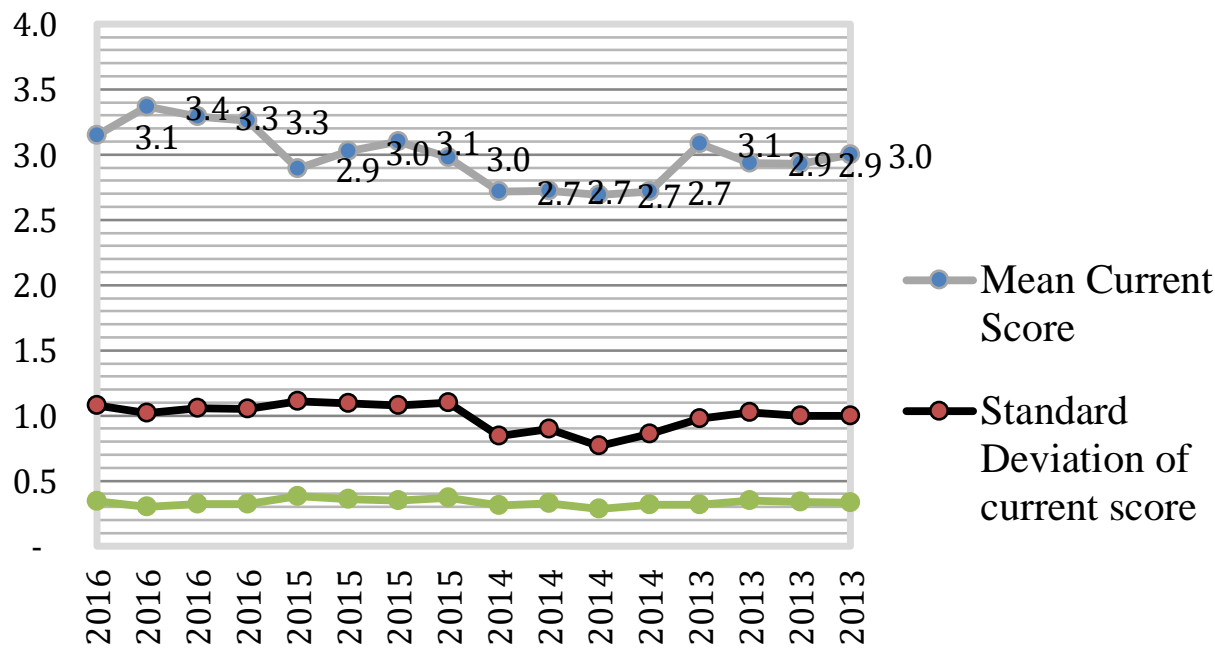

Figure 1 Level of Lean Implementation-Mean Current State Score- between 2013 and 2016, Category 
In Figure 1, the scores for the current state averages, for each of the four years, is plotted, along with the standard deviation and the coefficient of variation. In Figure 2, the same are shown for the future state scores. The sequence of plotting the points is: consolidated, Section I, Section II and Section III, reading right to left, for each year. A comparison between the current and the future state scores is shown in Figure 3.

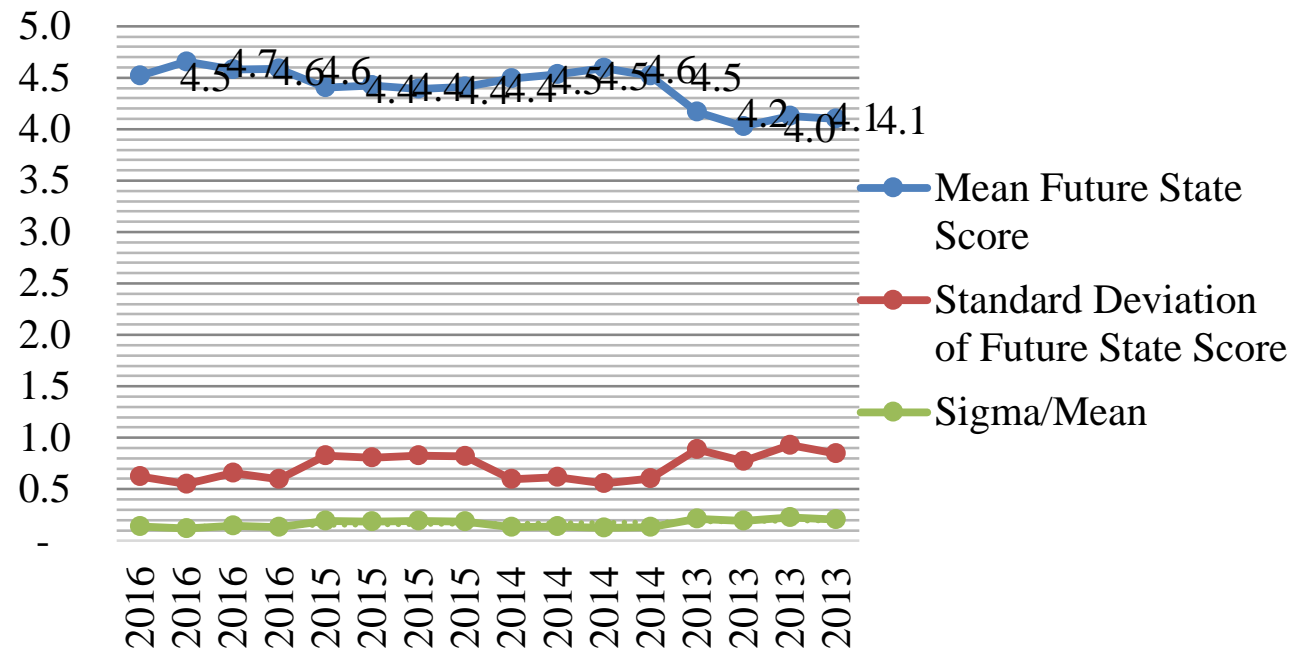

Figure 2 Level of Lean Implementation-Mean Future State Score - between 2013 and 2016, Category Wise and Consolidated

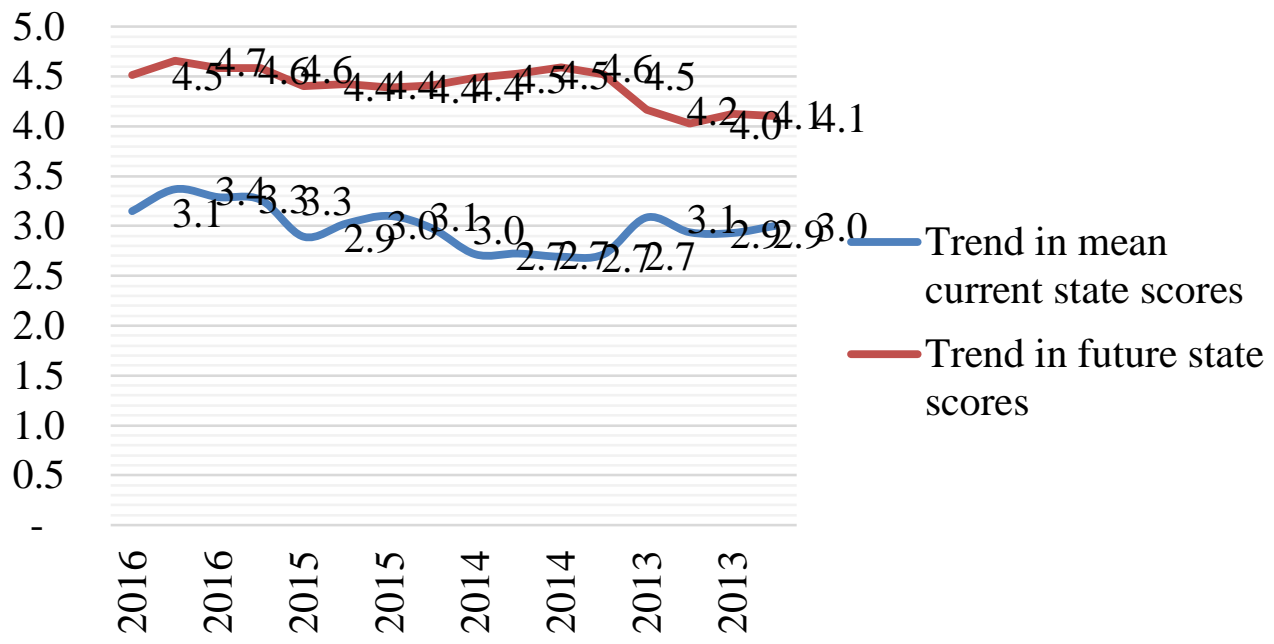

Figure 3 Trend of Mean Future and Current State Scores between the Years 2013 and 2016, Category Wise and Consolidated

A consolidated summary of the various data displayed in the Figures 1 to 4 , is shown in Table 7 below, along with the moving averages, Table 8: 
Table 7 Data on the Current State, Desired State and Gap, as shown in Figures 1 to 4

\begin{tabular}{|c|c|c|c|c|c|c|c|c|c|c|}
\hline & \multirow{2}{*}{ Year } & \multicolumn{3}{|c|}{ Current State Data } & \multicolumn{3}{|c|}{ Desired State Data } & \multicolumn{3}{|c|}{ Gap Data } \\
\hline & & Mean & $\begin{array}{l}\text { Std } \\
\text { Dev }\end{array}$ & $\mathrm{CV}$ & Mean & $\begin{array}{l}\text { Std } \\
\text { Dev }\end{array}$ & $\mathrm{CV}$ & Mean & $\begin{array}{l}\text { Std } \\
\text { Dev }\end{array}$ & $\mathrm{CV}$ \\
\hline 2016 & Section I & 3.15 & 1.08 & 0.34 & 4.52 & 0.62 & 0.14 & 1.37 & 1.13 & 0.82 \\
\hline 2016 & Section II & 3.37 & 1.02 & 0.30 & 4.66 & 0.55 & 0.12 & 1.29 & 1.09 & 0.85 \\
\hline 2016 & Section III & 3.28 & 1.06 & 0.32 & 4.58 & 0.66 & 0.14 & 1.28 & 1.12 & 0.88 \\
\hline 2016 & $\begin{array}{l}\text { LESAT } \\
\text { Overall }\end{array}$ & 3.26 & 1.05 & 0.32 & 4.58 & 0.60 & 0.13 & 1.32 & 1.11 & 0.84 \\
\hline 2015 & Section I & 2.89 & 1.11 & 0.38 & 4.40 & 0.83 & 0.19 & 1.51 & 1.07 & 0.71 \\
\hline 2015 & Section II & 3.02 & 1.09 & 0.36 & 4.42 & 0.80 & 0.18 & 1.40 & 1.06 & 0.76 \\
\hline 2015 & Section III & 3.10 & 1.08 & 0.35 & 4.39 & 0.83 & 0.19 & 1.29 & 1.04 & 0.81 \\
\hline 2015 & $\begin{array}{l}\text { LESAT } \\
\text { Overall }\end{array}$ & 2.98 & 1.10 & 0.37 & 4.41 & 0.82 & 0.19 & 1.44 & 1.06 & 0.74 \\
\hline 2014 & Section I & 2.72 & 0.85 & 0.31 & 4.49 & 0.60 & 0.13 & 1.67 & 1.04 & 0.63 \\
\hline 2014 & Section II & 2.72 & 0.90 & 0.33 & 4.53 & 0.62 & 0.14 & 1.65 & 1.11 & 0.67 \\
\hline 2014 & Section III & 2.69 & 0.77 & 0.29 & 4.59 & 0.56 & 0.12 & 1.68 & 1.00 & 0.59 \\
\hline 2014 & $\begin{array}{l}\text { LESAT } \\
\text { Overall }\end{array}$ & 2.72 & 0.86 & 0.32 & 4.52 & 0.60 & 0.13 & 1.66 & 1.07 & 0.64 \\
\hline 2013 & Section I & 3.09 & 0.98 & 0.32 & 4.17 & 0.89 & 0.21 & 1.08 & 1.14 & 1.05 \\
\hline 2013 & Section II & 2.94 & 1.02 & 0.35 & 4.03 & 0.77 & 0.19 & 1.09 & 1.15 & 1.06 \\
\hline 2013 & Section III & 2.93 & 1.00 & 0.34 & 4.13 & 0.93 & 0.23 & 1.22 & 1.17 & 0.96 \\
\hline 2013 & $\begin{array}{l}\text { LESAT } \\
\text { Overall }\end{array}$ & 3.00 & 1.00 & 0.33 & 4.10 & 0.84 & 0.21 & 1.10 & 1.15 & 1.04 \\
\hline
\end{tabular}

The moving average scores, of the current and desired state average scores, clearly show that the current state has improved from 2.86 to 3.12, Table 8, an improvement of about $9 \%$. The same data for the desired state shows a movement from 4.31 to 4.5 , Table 8. Both these numbers and trends show that the LMLII's have the intent to continue to improve LMM, and they are moving up in the desired direction. The fouryear average current state score is 2.989 , and the corresponding desired score is 4.4, the gap being about 1.4. This augurs well for the future of LM. The coefficient of 
variation values are low in the case of the desired state mean scores, lower than in the case of the current scores, Table 7. This is indicative of a larger spread in the current scores data than the future scores, resulting from a more uniform perception of the aspiration to achieve a good level of LM implementation, but differing views on where the LMLII are in the journey currently. There appears to be a consensus in the LMLII that a high level of LMM is desirable. However, the higher spread in the current state scores could be indicative of differential achievements by individual respondents. The higher differential perception could also be because of a lack of uniform understanding of what LM is all about. Many researchers have mentioned this fact, that there is still a lack of a single definition of LM (Urban, 2015).

Table 8 Moving Averages

\begin{tabular}{|l|c|c|c|c|}
\cline { 2 - 5 } \multicolumn{1}{c|}{} & $\mathbf{2 0 1 3}$ & $\mathbf{2 0 1 4}$ & $\mathbf{2 0 1 5}$ & $\mathbf{2 0 1 6}$ \\
\hline LESAT CS annual average & 3.00 & 2.72 & 2.98 & 3.26 \\
\hline LESAT CS moving average & NA & 2.86 & 2.85 & 3.12 \\
\hline LESAT DS annual average & 4.10 & 4.52 & 4.41 & 4.58 \\
\hline LESAT DS moving average & NA & 4.31 & 4.47 & 4.50 \\
\hline LESAT Gap annual data & 1.10 & 1.66 & 1.44 & 1.32 \\
\hline LESAT Gap moving average & NA & 1.38 & 1.55 & 1.38 \\
\hline Section I CS moving average & NA & 2.90 & 2.80 & 3.02 \\
\hline Section II CS moving average & NA & 2.83 & 2.87 & 3.20 \\
\hline Section III CS moving average & NA & 2.81 & 2.90 & 3.19 \\
\hline Section I DS moving average & NA & 4.33 & 4.45 & 4.46 \\
\hline Section II DS moving average & NA & 4.28 & 4.48 & 4.54 \\
\hline Section III DS moving average & NA & 4.36 & 4.49 & 4.48 \\
\hline
\end{tabular}

The 'absolute level' of the current state section scores has varied between 2.72 and 3.37, Table 7, which is low compared with the desired state scores, which show a variation between 4.03 to 4.66 , Table 7 . While the Section I averages vary between 2.72 to 3.15, with the averages in 2013 and 2016 at 3.09 and 3.15 respectively, Section II averages vary between 2.72 to 3.37 , while the Section III vary between 2.69 and 3.28. The overall average scores vary between 2.72 to 3.26 . The variations are range bound and move in a narrow band, however, over the four-year period, there is an improving trend.

The moving averages shown in Table 8 can be studied to gain a better understanding of the trends of the 3 sections. The section I current state has moved from 2.9 to 3.02, section II from 2.83 to 3.20 and section III from 2.81 to 3.19 . While all three have moved up, section III has shown the maximum improvement. This is a clear indication of LMM. In any movement, in the early stages, the maximum improvement can be seen in the leadership engagement and guidance, viz., section I. Further, if the section I scores improve continuously, then the section II and III start moving up too, as the 
maturity of the movement, triggered and supported by the leadership, starts to move up. In overall terms, when the sections II and III scores show a healthy trend, then the implication is that the maturity is on the rise. A similar improving trend is also seen in the desired state moving section averages, indicating a greater confidence in the respondents, confirming the maturity improvement trend shown by the current state scores. It is possible that, when respondents see improvements on the ground, caused due to their efforts, then their confidence gets a boost, leading to setting of more stretch targets.

The year 2014 witnessed the lowest absolute level scores in line with the political and industrial scenario in India at that time, both of which were passing through a period of great uncertainty, with no decisions forthcoming. Investment from industry was at a standstill and performance of Indian companies went through a difficult phase. Also, Section I scores are the lowest in comparison with categories II and III, as is the consolidated score, too. The scores are the highest in the year 2016.

The scores of the desired state averages, Table 8, indicate that between 2013 and 2016, they have been between 4.10 to 4.58. The LMLII have been raising the bar of expectations in spite of the low absolute level actual scores. It would appear that the actuals have not been in keeping with expectations primarily due to external conditions. Another way to look at this would be to conclude that the high expectations have kept the actuals also at a consistent level, without letting them fall further below 2.72, the lowest achieved in the four years. In spite of the poor external conditions, LMLII have tried to keep up their morale.

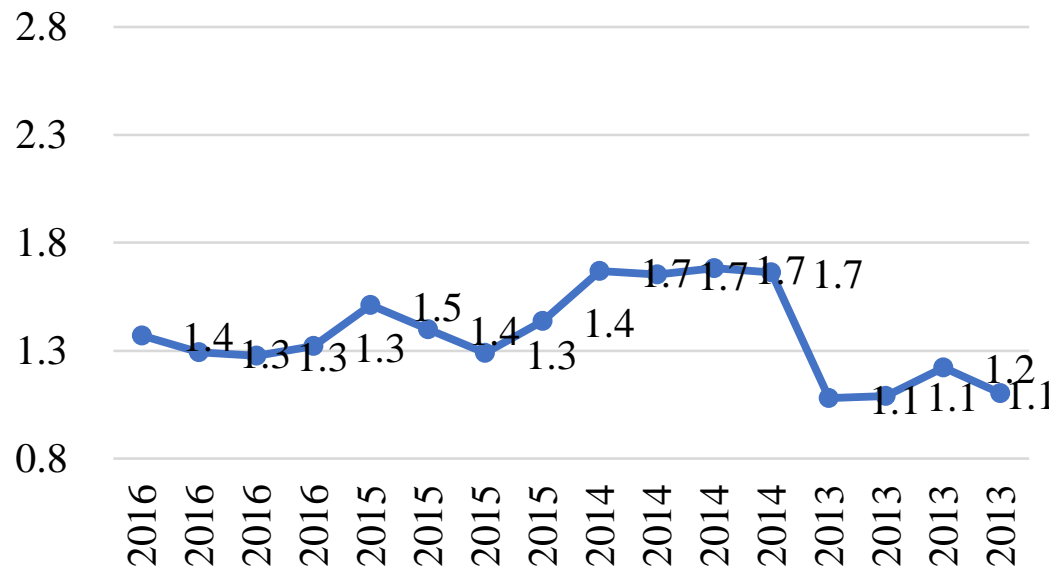

Figure 4 Trend of the Gap between the Mean Future and Current State Scores between the Years 2013 and 2016, Category Wise and Consolidated

The trend of each of the categories' overall average current and desired state scores is shown in Figures 4 and 5. The Figures show how Lean implementation is evolving with respect to the earlier discussed LESAT sections I, II, and III. Both, current state and desired state scores show similar trends, however, the gap between the two has gone up from 1.10 in 2013 to 1.32 in 2016 , indicating that the actuals are falling below 
expectations. The gap has been the highest in 2014, at 1.66. Between 2014 and 2016, the gap has closed, from 1.66 to 1.32 .

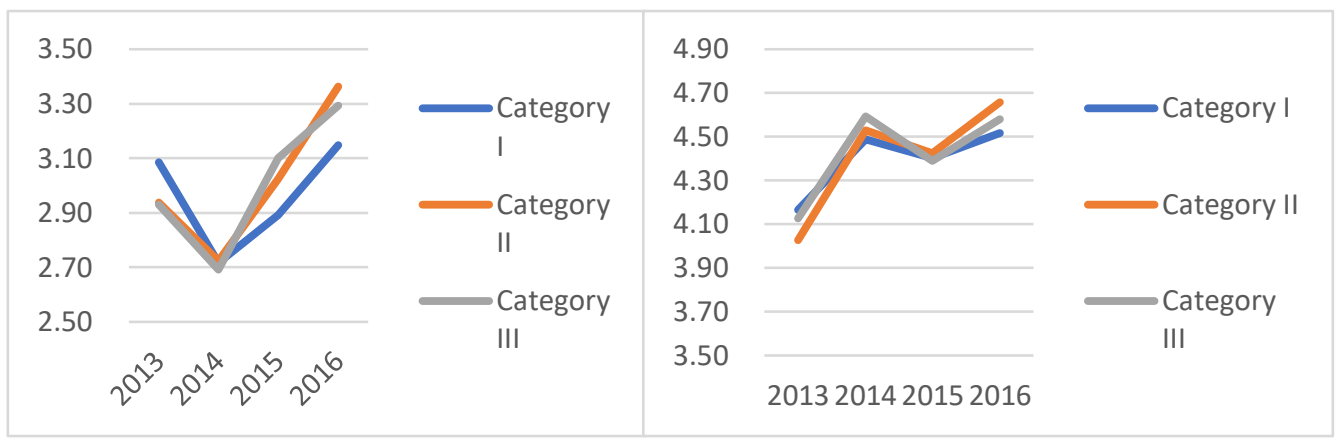

Figure 5 Trend of Overall Average Current (left) and Future (right) Scores Across Four Years (2013-2016)

In comparing the overall means, apart from the section means, which has been shown in Figure 5 above, it's striking, that, in the year 2014, the desired state overall average has trended up (1.66) whereas the current state average has come down (2.72), indicating that the gap is due to the absence of enabling infrastructure, e.g., lack of follow-up actions on leadership directives, lack of focus on activities identified for improvement, lack of middle management involvement in the movement. It is also significant to note that the trend of the average desired state scores has gone down between 2014 and 2015, could be a reaction to the down-trend of the actuals in the period 2013-2014.

In closing, it is checked whether the variations in the average scores over the years are statistically significant or not. For this purpose, the one-tailed and the two-tailed ttests have been used, to study the differences between the mean scores, in pairs. Results show that the difference in the means of all the LESAT section absolute scores are statistically significant (but less than 0.3 , that is $10 \%$ ), indicating that there is a difference in the scores between the years 2013 and 2016, showing an improvement in the maturity level of Lean implementation (Table 9).

From the Table 9, it is evident that the overall, Section II and Section III scores have improved between 2013 and 2016. On the other hand, Section I scores have not improved statistically significantly, although there is an improvement. Overall, one can say that, over the period 2013 - 2016, the LM in the LMLII has improved.

\subsection{RQ2: Identifying Factors that can Characterize the Implementation of LM in the LMLII}

In order to identify the factors responsible for the state of LM in the LMLII, we have devised a method which is applied in two parts.

\subsubsection{Analysis Methodology}

We have looked at the survey results in two ways. One, the short term, and the second, the long term. The short-term variables are identified by the EFA runs for each year, 'individual period analysis', whereas the long-term variables are identified by the EFA run on the combined, four-year data, 'combined analysis'. By doing an EFA for each 
year, we can identify the variables that load significantly on component factors, which can explain a large part of the variance. These variables affect the one-year LMM.

Table 9 t-Tests to Compare Means between Two Years (2016 and 2013)

\begin{tabular}{|c|c|c|c|c|}
\hline Year & LESAT Categories & $\begin{array}{c}\text { Two or one } \\
\text { tailed }\end{array}$ & p-Value & Conclusion \\
\hline $\begin{array}{l}2016 \text { and } 2013- \\
\text { current state } \\
\text { data }\end{array}$ & $\begin{array}{l}\text { Compare the means of } \\
\text { average Section I scores }\end{array}$ & Two-tailed & 0.1500 & $\begin{array}{l}\text { Null hypothesis } \\
\text { accepted. Means are } \\
\text { not significantly } \\
\text { different }\end{array}$ \\
\hline $\begin{array}{l}2016 \text { and } 2013- \\
\text { current state } \\
\text { data }\end{array}$ & $\begin{array}{l}\text { Compare the means of } \\
\text { average Section II } \\
\text { scores }\end{array}$ & Two-tailed & - & $\begin{array}{l}\text { Null hypothesis } \\
\text { rejected. Means are } \\
\text { significantly different }\end{array}$ \\
\hline $\begin{array}{l}2016 \text { and } 2013- \\
\text { current state } \\
\text { data }\end{array}$ & $\begin{array}{l}\text { Compare the means of } \\
\text { average Section III } \\
\text { scores }\end{array}$ & Two-tailed & - & $\begin{array}{l}\text { Null hypothesis } \\
\text { rejected. Means are } \\
\text { significantly different }\end{array}$ \\
\hline $\begin{array}{l}2016 \text { and } 2013- \\
\text { current state } \\
\text { data }\end{array}$ & $\begin{array}{l}\text { Compare the means of } \\
\text { average overall Section } \\
\text { scores }\end{array}$ & Two-tailed & 0.0300 & $\begin{array}{l}\text { Null hypothesis } \\
\text { rejected. Means are } \\
\text { significantly different }\end{array}$ \\
\hline $\begin{array}{l}2016 \text { and } 2013- \\
\text { desired state } \\
\text { data }\end{array}$ & $\begin{array}{l}\text { Compare the means of } \\
\text { average Section I scores }\end{array}$ & Two-tailed & - & $\begin{array}{l}\text { Null hypothesis } \\
\text { rejected. Means are } \\
\text { significantly different }\end{array}$ \\
\hline $\begin{array}{l}2016 \text { and } 2013- \\
\text { desired state } \\
\text { data }\end{array}$ & $\begin{array}{l}\text { Compare the means of } \\
\text { average Section II } \\
\text { scores }\end{array}$ & Two-tailed & - & $\begin{array}{l}\text { Null hypothesis } \\
\text { rejected. Means are } \\
\text { significantly different }\end{array}$ \\
\hline $\begin{array}{l}2016 \text { and } 2013- \\
\text { desired state } \\
\text { data }\end{array}$ & $\begin{array}{l}\text { Compare the means of } \\
\text { average Section III } \\
\text { scores }\end{array}$ & Two-tailed & - & $\begin{array}{l}\text { Null hypothesis } \\
\text { rejected. Means are } \\
\text { significantly different }\end{array}$ \\
\hline $\begin{array}{l}2016 \text { and } 2013- \\
\text { desired state } \\
\text { data }\end{array}$ & $\begin{array}{l}\text { Compare the means of } \\
\text { average overall Section } \\
\text { scores }\end{array}$ & Two-tailed & - & $\begin{array}{l}\text { Null hypothesis } \\
\text { rejected. Means are } \\
\text { significantly different }\end{array}$ \\
\hline $\begin{array}{l}2016 \text { and } 2013- \\
\text { desired state } \\
\text { data }\end{array}$ & $\begin{array}{l}\text { Compare the means of } \\
\text { average overall Section } \\
\text { scores }\end{array}$ & One-tailed & 0.7400 & $\begin{array}{l}\text { Null hypothesis } \\
\text { accepted. The } \\
\text { difference in means } \\
\text { is greater than } 0.1\end{array}$ \\
\hline $\begin{array}{l}2016 \text { and } 2013- \\
\text { desired state } \\
\text { data }\end{array}$ & $\begin{array}{l}\text { Compare the means of } \\
\text { average overall Section } \\
\text { scores }\end{array}$ & One tailed & 0.2500 & $\begin{array}{l}\text { Null hypothesis } \\
\text { accepted. The } \\
\text { difference in means } \\
\text { is greater than } 0.2\end{array}$ \\
\hline $\begin{array}{l}2016 \text { and } 2013- \\
\text { desired state } \\
\text { data }\end{array}$ & $\begin{array}{l}\text { Compare the means of } \\
\text { average overall Section } \\
\text { scores }\end{array}$ & One tailed & 0.0500 & $\begin{array}{l}\text { Null hypothesis } \\
\text { rejected. The } \\
\text { difference in means } \\
\text { is NOT greater than }\end{array}$ \\
\hline $\begin{array}{l}2016 \text { and } 2013- \\
\text { desired state } \\
\text { data }\end{array}$ & $\begin{array}{l}\text { Compare the means of } \\
\text { average overall Section } \\
\text { scores }\end{array}$ & One-tailed & 0.0068 & $\begin{array}{l}\text { Null hypothesis } \\
\text { rejected. The } \\
\text { difference in means } \\
\text { is NOT greater than }\end{array}$ \\
\hline
\end{tabular}


LMM is a serial process, with companies identifying strengths and weaknesses, using the PDCA techniques as mentioned in the Baldrige Model or TQM literature. Strengths are further improved upon, and weaknesses are addressed through new initiatives, to fill up the gaps. Hence, in any such continuously improving process, one can expect to find variables which affect the LMM outcomes in the short term as well as in the long term. Those variables, which are common in all the years, can be called as the 'long term' enablers, whereas the short-term affecting variables are 'short term' enablers. In the ideal case, both short term and long-term variables would be the same. However, there are causal factors which can lead to some short-term variables being the enabler in year 1 , but not in year 2 , and so on.

Thus, in the second part of our analysis, 'combined analysis', we gathered all the 'common variables' identified each year by the yearly EFA, and did one EFA for the full, four-year data. This EFA identified the 'long term' variables.

Having identified the long-term variables using the combined, four-year data, we used the long-term variables to run EFA's for each year. The logic in doing so is that, if the long-term variables are able to explain a significant part of the yearly variance, then these become the variables which need to be addressed every year, to improve the LMM. This implies that the substitutability between the short term and long-term variables is possible, and this is true, if the Bartlett Sphericity Index values are close to zero. This is the third and concluding part of our analysis methodology, called 'reverse EFA confirmatory analysis'.

To summarize, part I is called the 'coupled analysis', part II is the 'combined analysis' and part III is called the 'reverse EFA confirmatory analysis'.

\subsubsection{Basis for Factor Analyses}

All EFA's were run using the IBM SPSS package version 25. EFA's were run using data for: 2013, 2014, 2015, 2016 and the consolidated data for all the four years 2013 to 2016. In each of the EFA runs, we used the determinant value, KMO measure of sampling and the Bartlett measure of sphericity to validate the runs. The ideal determinant value desired is zero. The KMO measure - or Kaiser Meyer Olkin measure of sampling adequacy - indicates the adequacy of sample size, with values above 0.6 as acceptable. Similarly, the Bartlett sphericity index shows the possibility for dimensional reduction, using EFA. If the significance is close to zero, then this possibility exists. For our purposes, we need the determinant close to zero, KMO above 0.6 and the Bartlett sphericity Test significance close to 0 . Of the five sets of factor analysis runs, only in one case (year 2013) was the KMO Measure of sampling adequacy at 0.571 , in all other cases, the same was above 0.9. The Bartlett sphericity index significance in ALL cases was at 0.000 , as were the determinant values. Thus, it was concluded that the factor analyses exercises were fully valid and acceptable for the exploratory type of research that has been attempted in this paper.

The reason for doing different analyses for each year was to identify the variables (each of the 68 questions included in the LESAT survey is a variable, which tracks the performance of the LMLII in the subject area addressed by the question) that characterize yearly progress of LM in that year. If the same factors are repeated every year, then these factors can be used to study LM in LMLII over the four-year period. Doing so would enable driving of LMM in the future years. However, changing priorities, differential resources allocations, changing profit profiles of products, new 
products introductions, all impose a plethora of demands on company managements and each company may respond in unique ways, in each year.

The Cronbach alpha values (with a minimum is 0.759 and the maximum is 0.97 ), as shown in Table 6 , are acceptable for exploratory research. The data for the year 2013 has the lowest alpha value whereas the other three years show alpha values over 0.9 .

\subsubsection{Individual Period Analysis}

The factor analyses are conducted according to the following steps:

Step-One: Use the full dataset of 68 variables and find out the Cronbach alpha of the datasets of 'current state' variables only. These have been reported in Table 6, column 1.

Step-Two: Using the 'scale if item deleted' matrix from the Cronbach alpha output option, a process of 'normalization' of the variables was undertaken using the annual data for 2013, 2014, 2015 and 2016, for each year, separately. For the factor analysis for each year, several variables were progressively eliminated from the dataset, till such a point where the Cronbach alpha was equal to 0.9 . This could be done for all datasets except for the year 2013 where the starting alpha was itself below 0.9 , at 0.759. In this case the Cronbach alpha was allowed to go down to 0.738 , with 16 variables. The idea was to get the best combination of maximum alpha and minimum variables.

Step-Three: The variables loading significantly $(>0.50)$ on factors for each year in the EFA's were isolated. There were, in all, 38 variables identified. While 15 variables were common, i.e., which were a part of the component factors in each of the four years, there were 23 others, which were not repeated in any year.

\subsubsection{Combined Analysis}

Step Four: These 38 variables were then used to run an EFA using the consolidated four-year data, of 741 observations, to identify the number of variables which can give a good fit. In two iterations, we found that 21 variables could explain $59 \%$ of the variation. We selected the results of this EFA run as the final set of factors, (see last column, Table 10), for further study.

Table 10 Summary of Parameters for Factor Analyses

\begin{tabular}{|l|c|c|c|c|c|}
\cline { 2 - 6 } \multicolumn{1}{c|}{} & 2013 data & 2014 data & 2015 data & 2016 data & $\begin{array}{c}\text { 2013 - 2016 } \\
\text { data }\end{array}$ \\
\hline $\begin{array}{l}\text { Cronbach alpha of data } \\
\text { with all 68 variables }\end{array}$ & 0.759 & 0.92 & 0.97 & 0.947 & 0.949 \\
\hline $\begin{array}{l}\text { Number of } \\
\text { observations (dataset) }\end{array}$ & 108 & 195 & 228 & 210 & 741 \\
\hline $\begin{array}{l}\text { Total number of } \\
\text { variables included for } \\
\text { factor analysis }\end{array}$ & 16 & 11 & 13 & 16 & 21 \\
\hline $\begin{array}{l}\text { Cronbach Alpha for } \\
\text { the variables included }\end{array}$ & 0.738 & 0.919 & 0.919 & 0.897 & 0.899 \\
\hline
\end{tabular}




\begin{tabular}{|l|c|c|c|c|c|} 
Type of rotation & $\begin{array}{l}\text { Varimax with } \\
\text { Kaiser } \\
\text { Normalization }\end{array}$ & $\begin{array}{l}\text { Promax with } \\
\text { Kaiser } \\
\text { Normalization }\end{array}$ & $\begin{array}{l}\text { Promax with } \\
\text { Kaiser } \\
\text { Normalization }\end{array}$ & $\begin{array}{l}\text { Varimax with } \\
\text { Kaiser } \\
\text { Normalization }\end{array}$ & $\begin{array}{l}\text { Promax with } \\
\text { Kaiser } \\
\text { Normalization }\end{array}$ \\
\hline $\begin{array}{l}\text { KMO measure of } \\
\text { sampling }\end{array}$ & 0.571 & 0.910 & 0.934 & 0.901 & 0.929 \\
\hline Significance value & 0.000 & 0.000 & 0.000 & 0.000 & 0.000 \\
\hline $\begin{array}{l}\text { Component factors } \\
\text { (total number) }\end{array}$ & 6 & 5 & 5 & 5 & 6 \\
\hline $\begin{array}{l}\text { Percentage variation } \\
\text { explained }\end{array}$ & 64 & 82 & 71 & 67 & 59 \\
\hline Extraction Method & EFA & EFA & EFA & EFA & EFA \\
\hline
\end{tabular}

The names of the six component factors, into which the 21 variables significantly load into, are listed in Table 11.

Table 116 Factors, 21 Variables and the Names of the Factors

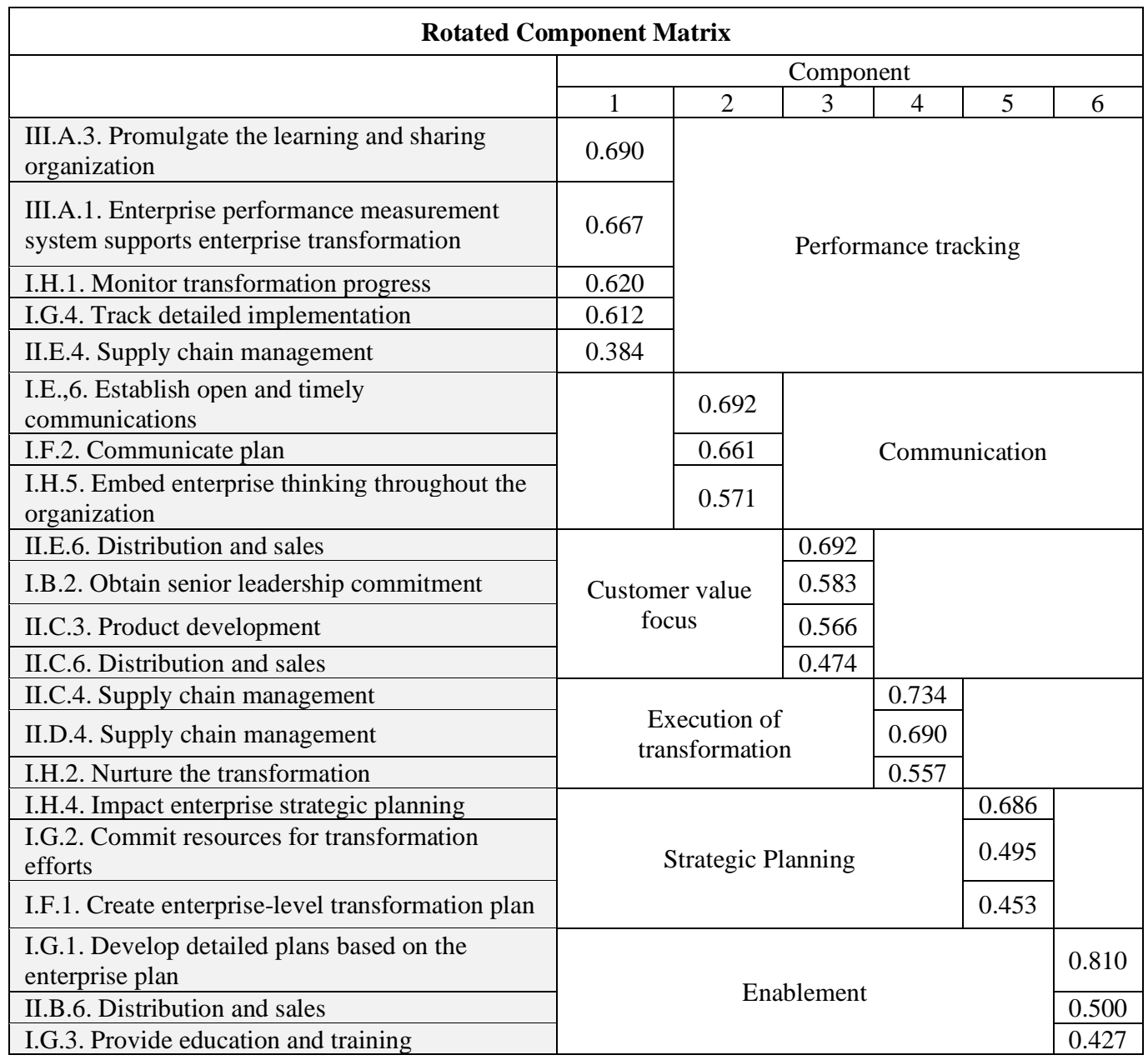




\subsubsection{Reverse EFA Confirmatory Analysis}

Step 5: The purpose of the combined analysis is to use both the individual year's data, as well as the four-year data, to identify those factors which can help explain LMM over the four years. Doing so, enables us to zero in on the variables which need to be tracked regularly, on a long-term basis, to ensure that the LMM improves continuously. However, the coupled analysis results have to be confirmed. That is, while we have identified the variables which can explain the variance in the four-year period, we also need to show that they can also explain the variance in each year, only then can the factors be accepted as representative of each year. For this purpose, we used these factors and ran EFA's for each year separately, and the results are summarized in Table 12 below:

Table 12 Showing the Results of EFA for each Year using 21 Factors (reverse EFA)

\begin{tabular}{|c|c|c|c|c|}
\hline Description & 2013 & 2014 & 2015 & 2016 \\
\hline $\begin{array}{l}\text { Number of observations } \\
\text { (dataset) }\end{array}$ & 108 & 195 & 228 & 210 \\
\hline Cronbach Alpha & 0.738 & 0.919 & 0.919 & 0.897 \\
\hline $\begin{array}{l}\text { Total number of variables for } \\
\text { factor analysis }\end{array}$ & 21 & 21 & 21 & 21 \\
\hline Type of rotation & $\begin{array}{l}\text { Varimax with } \\
\text { Kaiser } \\
\text { Normalizatio } \\
\mathrm{n}\end{array}$ & $\begin{array}{l}\text { Varimax with } \\
\text { Kaiser } \\
\text { Normalizatio } \\
\mathrm{n}\end{array}$ & $\begin{array}{l}\text { Varimax with } \\
\text { Kaiser } \\
\text { Normalizatio } \\
\mathrm{n}\end{array}$ & $\begin{array}{l}\text { Varimax with } \\
\text { Kaiser } \\
\text { Normalizatio } \\
\mathrm{n}\end{array}$ \\
\hline KMO measure of sampling & 0.509 & 0.860 & 0.909 & 0.838 \\
\hline Significance value & 0 & 0 & 0 & 0 \\
\hline Determinant value & 0.031 & 0 & 0 & 0 \\
\hline $\begin{array}{l}\text { Component factors (total } \\
\text { number) }\end{array}$ & 9 & 5 & 6 & 6 \\
\hline Percentage variation explained & 66 & 65 & 68 & 64 \\
\hline
\end{tabular}

From Table 12, it is evident that the reverse EFA results are acceptable. In the results for the year 2013, the value of KMO is slightly lower than the permissible 0.6 , and the determinant value is higher than the preferred value of zero. However, the explanation of the variance is acceptable. The question that needs to be answered is: why is it that the 21 variables, which are able to explain variances of over $65 \%$, have not been identified in the yearly EFA runs done during the coupled analysis? Why is it that the yearly runs have thrown up different variables than the 21 finally identified by the coupled analysis? The reasons could be that the differences in the loadings between these 21 and the other variables are marginal. Some of the 21 variables could have been on the periphery of the solutions set, and hence, missed out in the yearly analysis. It is also possible that some of the variables not included in the list of 21, could also explain the variance equally well. What this means is - each variable loading significantly on the component factors is important every year, but, some, as listed in the 21 variables, have to be consistently addressed, so that the LMM improves continuously. This is the major advantage with the combined analysis and the reverse 
EFA confirmatory analysis method. The method can identify both types of variables, those which affect significantly in the short term, and those which affect in the long term. The long-term variables are important from the maturity point of view.

\subsubsection{Explanation of the Factor Analysis Results}

The six component factors, which have been identified by the analyses, and named, are shown in Figure 6.

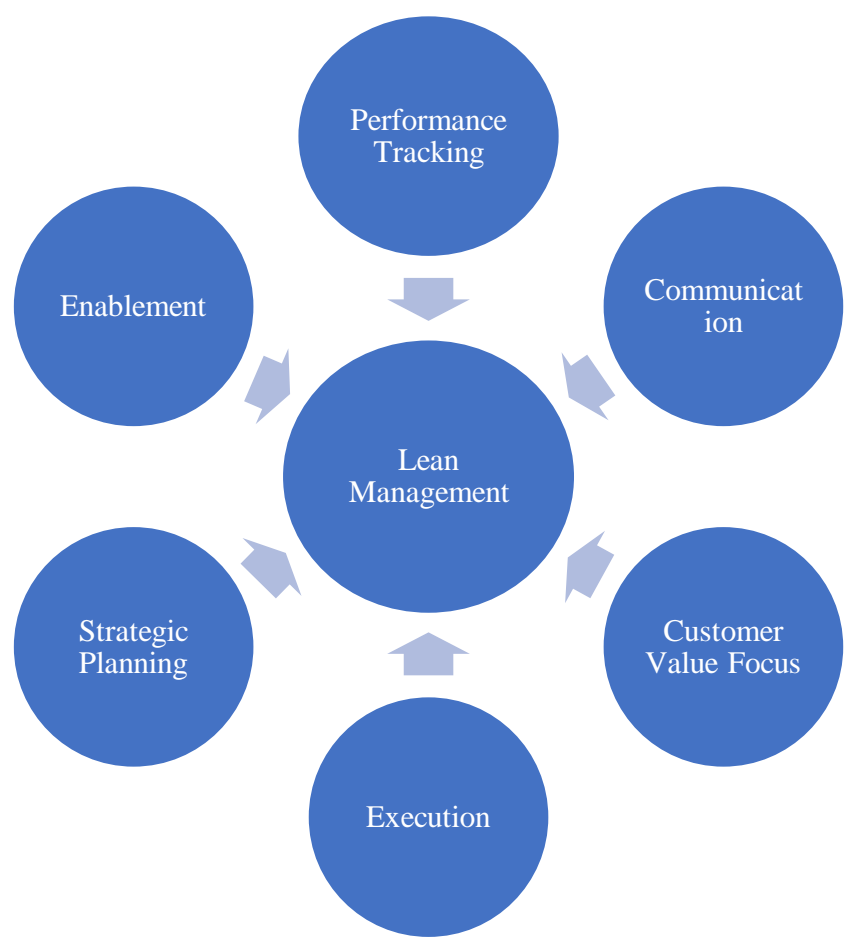

Figure 6 The Six Elements of Organizational Management that Facilitate Lean Management Implementation in Organizations

The nomenclature of the component factors is in alignment with other improvement movements as well as the Kotter framework (Kotter,2007) for organizational transformation. For example, strategic planning, tracking performance, communication, enabling employees to give off their best are all aligned with best practices in driving PDCA. The 21 variables cover all the three categories of LESAT. It is also significant that these 21 variables are amongst those that have the highest mean values over the period $2013-2016$, with the exception of four items. Of the 21 variables which have loaded favourably on the six component factors, 12 are from Section I, 7 from Section II and 2 from Section III. The predominance of variables from Section I confirms that leadership involvement and engagement continue to be of primary importance. In spite of the several advancements in technology, IT infrastructure and speedier communications through IOT, top management engagement in the initiatives is imperative. The other 9 variables relate to 
performance, execution and management. It appears that the PDCA methodology has become the norm in the LMLII, as, no factor relating to continuous improvement has been included in the 21 variables. Nevertheless, we may need more studies to confirm this conclusion.

Implementation of LM is similar to the practice of business excellence (BE) as exemplified in the Malcolm Baldrige and the EFQM models (Rajpal and Sagar, 2003, Brown, 2008, Jayaraman, 2013, Dawei Lua et al, 2011). These models are used for organizational transformation, and improving performance continuously. If we look at the essence of these models and the Kotter framework, we will find that they are centred around the concepts of:

- Envision the future (creating a vision)

- Leadership involvement and engagement, creating a 'guiding coalition'

- Remove obstacles to change, create short term wins (low hanging fruits)

- Train and communicate the change to all the stakeholders, especially employees who are the prime movers, empower employees

Table 13 How the Component Factors in this Study Fit in with the Established 'Continuous Improvement/ Business Excellence' Models

\begin{tabular}{|c|c|c|c|c|}
\hline $\begin{array}{c}\text { Malcolm } \\
\text { Baldrige } \\
\end{array}$ & EFQM & Kotter & $\begin{array}{c}\text { Pillars of organizational } \\
\text { transformation }\end{array}$ & $\begin{array}{l}\text { Factors identified } \\
\text { from this study }\end{array}$ \\
\hline Leadership & Leadership & $\begin{array}{l}\text { Establish a sense } \\
\text { of urgency }\end{array}$ & $\begin{array}{l}\text { Leadership involvement } \\
\text { and engagement }\end{array}$ & $\begin{array}{l}\text { Leadership } \\
\text { direction and } \\
\text { involvement }\end{array}$ \\
\hline $\begin{array}{l}\text { Strategic } \\
\text { Planning }\end{array}$ & Strategy & $\begin{array}{l}\text { Form a powerful } \\
\text { guiding coalition, } \\
\text { Create a vision }\end{array}$ & $\begin{array}{l}\text { Envision the future, } \\
\text { practice PDCA and } \\
\text { SDCA to sustain the } \\
\text { change }\end{array}$ & $\begin{array}{l}\text { Planning and } \\
\text { actioning }\end{array}$ \\
\hline Customer focus & $\begin{array}{l}\text { Partnerships } \\
\text { and resources }\end{array}$ & $\begin{array}{c}\text { Communicate the } \\
\text { vision }\end{array}$ & & $\begin{array}{l}\text { Customer value } \\
\text { focus }\end{array}$ \\
\hline $\begin{array}{l}\text { Information and } \\
\text { knowledge } \\
\text { management }\end{array}$ & & $\begin{array}{l}\text { Plan for and } \\
\text { create short term } \\
\text { wins }\end{array}$ & $\begin{array}{l}\text { Train and communicate } \\
\text { the change to all } \\
\text { stakeholders, especially } \\
\text { employees, who are the } \\
\text { prime movers }\end{array}$ & $\begin{array}{l}\text { Program } \\
\text { management }\end{array}$ \\
\hline $\begin{array}{l}\mathrm{HR} \\
\text { management }\end{array}$ & People & $\begin{array}{l}\text { Empower others } \\
\text { to act on the } \\
\text { vision }\end{array}$ & $\begin{array}{l}\text { Remove obstacles to } \\
\text { change }\end{array}$ & $\begin{array}{l}\text { Create conditions } \\
\text { for employees to } \\
\text { practice LM }\end{array}$ \\
\hline $\begin{array}{l}\text { Processes } \\
\text { management }\end{array}$ & $\begin{array}{l}\text { Processes, } \\
\text { products and } \\
\text { services }\end{array}$ & $\begin{array}{l}\text { Consolidate } \\
\text { improvements } \\
\text { and produce } \\
\text { more change }\end{array}$ & $\begin{array}{l}\text { Guide the change through } \\
\text { usage of tools and } \\
\text { techniques, such as, } \\
\text { TQM, hoshin kanri, } \\
\text { balanced score card, } \\
\text { quality planning }\end{array}$ & $\begin{array}{l}\text { Utilisation of } \\
\text { resources and } \\
\text { process control }\end{array}$ \\
\hline $\begin{array}{l}\text { Results } \\
\text { management }\end{array}$ & Results & $\begin{array}{l}\text { Institutionalize } \\
\text { new approaches }\end{array}$ & $\begin{array}{l}\text { Embed the change in the } \\
\text { organization through } \\
\text { repeated usage and } \\
\text { deepening employee } \\
\text { work practices }\end{array}$ & Enablement \\
\hline
\end{tabular}

- Guide the change through usage of tools and techniques, such as, TQM, hoshin kanri, balanced scorecards, quality planning 
- Embed the change in the organization through repeated usage and deepening employee work practices

- $\quad$ Practice PDCA and SDCA to sustain the change

Based on the above "pillars of organizational transformation", many companies have successfully changed their work culture and become world leaders (Muthuraman, et al, 2014). LM is also a methodology which uses the above framework to bring about organizational change, to drive superior performance and sustained avoidance of waste. The key concepts of the various change frameworks listed in the above paragraphs and a comparison of the same with the results obtained in our factor analysis are summarized below in Table 13.

There are many similarities between the frameworks of the different models and the six component factors identified by this study. For example, involving and engaging leaders is a given in all the models. In the same way, any organizational change can be undertaken only with the enablement, training and engagement of employees, the prime movers of such change. What is emphasized in the Baldrige model is the use of refined tools and techniques, which is also at the heart of LM. LM is not a commonsense methodology, it involves the study, understanding and use of certain tools and techniques, for example, Gemba, JIT, reduction of Muda, and so on, which are unique to LM. Just as, Baldrige encourages the use of TQM, PDCA, customer value management, etc. Unless such refined tools and techniques are used, transformational efforts will not result in sustained improvements. Modern organizations are complex organisms which need special applications to instill team work, collaboration, commonality of purpose and alignment across specialized functions, for which special tools and techniques have been designed and practiced over the years. Thus, the alignment of the six component factors from our study with the established models for organizational transformations proves the authenticity and credibility of the study.

\subsection{RQ3: Can these factors be used to track LM changes in the LMLII? And used in place of the MIT's LESAT survey instrument in India?}

The 21 variables load reasonably well on the components. However, the explanation of the variance could be better than the $59 \%$. While the Cronbach alpha number, the $\mathrm{KMO}$ and the Bartlett sphericity significance levels are quite good, still, to be cautious, we feel that we should continue the study for a few more years, and then check out the same above parameters. If the fit improves, in that, the 'percentage of variation explained' goes up, then there could be a good case. Till then we could continue with the LESAT instrument. Secondly, it is important to note that the 21 variables are for long term maturity, and, in the short term, it is still necessary to drive the other variables too.

\section{Conclusions}

Using a well-validated instrument, the LESAT, designed by the LAI - MIT, to collect data from LMLII over a four-years period, this study has identified systematically, the status of LM practice in the LMLII. The overall average current state scores have improved in the period 2013 to 2016 , and the factors responsible for this improvement 
have been identified from the factor analyses. The individual period - combinedreverse EFA analysis method has identified the 21 variables which drive the long term LMM.

A deeper analysis, for the improvement in LM deployment in the LMLII's, especially in the year 2016, identifies 10 variables, mostly from Section II, in the year 2016, that have scored over 3.5 average. There is almost no other variable so identified in the years $2013-2015$. This is a positive development. The factors include senior management commitment, production, supply chain management, product development and sales and distribution management. These are all key areas covered by LM and shown in Table 14 below:

Table 14 List of 'High Scoring' Factors in the Years 2013 to 2016

\begin{tabular}{|c|c|c|}
\hline Decision Criteria & $\begin{array}{l}\text { Current } \\
\text { State Mean }\end{array}$ & Variance \\
\hline & $>3.5$ & $<1.5$ \\
\hline List of Enterprise Practices & $\begin{array}{l}\text { Data for } \\
2016\end{array}$ & \\
\hline Number of Practices meeting conditions: & 10 & \\
\hline List of Practices Meeting Conditions & $\begin{array}{l}\text { Current } \\
\text { State }\end{array}$ & Variance \\
\hline I.B.2. Obtain senior leadership commitment & 3.6 & 1.1 \\
\hline II.A.1. Program management - Enterprise Capabilities & 3.6 & 0.9 \\
\hline II.A.4. Supply chain management - Enterprise Capabilities & 3.6 & 1.4 \\
\hline II.A.5. Production - Enterprise Capabilities & 3.6 & 0.9 \\
\hline II.B.3. Product development - Network-Wide Performance & 3.5 & 1.0 \\
\hline II.B.5. Production - Network-Wide Performance & 3.5 & 1.3 \\
\hline II.C.3. Product development - Customer Value & 3.5 & 1.1 \\
\hline II.D.4. Supply chain management - Upstream Stakeholders & 3.6 & 1.0 \\
\hline $\begin{array}{l}\text { II.E.1. Program management - Monitoring and Risk } \\
\text { Management }\end{array}$ & 3.5 & 1.1 \\
\hline $\begin{array}{l}\text { II.E.6. Distribution and sales - Monitoring and Risk } \\
\text { Management }\end{array}$ & 3.6 & 1.2 \\
\hline List of Enterprise Practices & $\begin{array}{l}\text { Data for } \\
2015\end{array}$ & \\
\hline Number of Practices meeting conditions: & 0 & \\
\hline List of Enterprise Practices & $\begin{array}{l}\text { Data for } \\
2014\end{array}$ & \\
\hline Number of Practices meeting conditions: & 3 & \\
\hline List of Practices Meeting Conditions & $\begin{array}{c}\text { Current } \\
\text { State } \\
\end{array}$ & Variance \\
\hline I.E.,6. Establish open and timely communications & 4.1 & 0.6 \\
\hline I.H.5. Embed enterprise thinking throughout the organization & 3.5 & 0.3 \\
\hline $\begin{array}{l}\text { III.A.5. Integration of environmental protection, health and } \\
\text { safety into the business }\end{array}$ & 3.6 & 0.5 \\
\hline List of Enterprise Practices & $\begin{array}{l}\text { Data for } \\
2013\end{array}$ & \\
\hline Number of Practices meeting conditions: & 0 & \\
\hline
\end{tabular}


The study has found that the gap between the future and current state scores of LM implementation has gone up to 1.9 in 2014 , and then narrowed down to 1.4 , in 2016 , showing improvement.

\section{Suggestions for further work}

Any work that tries to capture the pulse of the LMLII needs to use a larger sample size, especially a longitudinal study. The involvement of more companies, more persons per company, more representative respondents, will help to improve data richness. Furthermore, according to Sharma et al., (2015), data sets on industrial characteristics in any of the four main geographical directions (i.e., North, East, West, and South) of India, can be considered as representing the whole of India. Nevertheless, the fact that the collected data is mainly from the west and north of India may imply some sampling bias. Future research on Lean evolution in India should enhance the (external) validity of this research by conducting more empirical studies, perhaps in a qualitative way, to identify the Indian cultural and societal aspects that hinder Lean evolution in India.

\section{References}

1. Amir Abolhassani, Ky Layfield, Bhaskaran Gopalakrishnan, (2016). Lean and US manufacturing industry: popularity of practices and implementation barriers, International Journal of Productivity and Performance Management, Vol. 65, Issue: 7 , pp.875-897

2. Anand, G. and Kodali, R. (2009), "Application of value stream mapping and simulation for the design of lean manufacturing systems: a case study", International Journal of Simulation and Process Modelling, Vol. 5 No. 3, pp.192204.

3. Begam, M.S., Swamynathan, R., \& Sekkizhar, J. (2013, December). Current Trends on Lean Management - A review. International Journal of Lean Thinking, 4(2), 15-21.

4. Bhamu, J., \& Sangwan, K.S. (2014). Lean manufacturing: literature review and research issues. International Journal of Operations \& Production Management, 34(7), 876-940.

5. Bhim Singh, (2016). Identification of lean implementation hurdles in Indian industry, International Journal of Social, Behavioural, Educational, Economic, Business and Industrial Engineering Vol:10, No:5, pp 1516 - 1520

6. Chakraborty, A., Biswas, S.N., \& Sarkar, S. (2013). Sustainable Development of Productivity Through Lean Manufacturing in Medium Enterprises. International Journal of Recent advances in Mechanical Engineering (IJMECH), 2 (1), 33-40.

7. Chaple, A.P., Narkhede, B.E., \& Akarte, M.M. (2014). Status of implementation of Lean manufacturing principles in the context of Indian industry: A Literature Review. 5th International \& 26th All India Manufacturing Technology, Design and Research Conference (AIMTDR 2014), IIT Guwahati, Assam, India, 567-16.

8. Chowdary, B.V., \& George, D. (2011). Improvement of manufacturing operations at a pharmaceutical company: A lean manufacturing approach. Journal of Manufacturing Technology Management, 23(1), 56-75. doi:10.1108/17410381211196285 
9. Damle, A.V., \& Nandurkar, K.N. (2011). Application of Value Stream Mapping in an Indian Automotive Industry: A Case Study. International Journal of Industrial Engineering Practice, 3(1), 19-26.

10. Dhandapani, V., Potter, A., \& Naim, M. (2004). Applying lean thinking: a case study of an Indian steel plant. International Journal of Logistics Research and Applications, 7(3), 239-250.

11. Doolen, Toni L. and Maria E. Hacker, (2005). A Review of Lean Assessment in Organizations: An Exploratory Study of Lean Practices by Electronics Manufacturers. Journal of Manufacturing Systems, Vol. 24, Issue 1, pp 55 - 67

12. Fullerton, Rosemary R., Frances A. Kennedy, Sally K. Widener, (2014). Lean Manufacturing and Firm Performance: The Incremental Contribution of Lean Management Accounting Practices, Journal of Operations Management (2014), pp 1 - 51, http://dx.doi.org/10.1016/j.jom.2014.09.002

13. Ghosh, M. (2012). Lean manufacturing performance in Indian manufacturing plants. Journal of Manufacturing Technology Management, 24(1), 113-122.

14. Gupta, S., \& Jain, S.K. (2013). A literature review of lean manufacturing. International Journal of Management Science and Engineering Management, 8(4), 241-249.

15. Gupta, V., Acharya, P., \& Patwardhan, M. (2013). A strategic and operational approach to assess the lean performance in radial tyre manufacturing in India: A case-based study. International Journal of Productivity and Performance Management, 62(6), 634-651.

16. Hallam, Cory R.A, (2003). Lean Enterprise as a self-assessment as a leading indicator for accelerating transformation in the aerospace industry. $\mathrm{Ph} \mathrm{D}$ thesis, MIT, pp 1 - 322

17. Hallam, Cory R. A, Jerome Keating, (2014). Company Self-Assessment of Lean Enterprise Maturity in the Aerospace Industry. Journal of Enterprise Transformation, Vol 4, Issue 1, pp 51-71

18. Hedeker, Gibbons, \& Waternaux. (1999). Sample size estimation for longitudinal designs with attrition. Journal of Educational and Behavioural Statistics, Vol 24, pp 70-93

19. Hopp, W.J., \& Spearman, M.L. (2004). To Pull or Not to Pull: What Is the Question?. Manufacturing \& Service Operations Management, 6(2), 133-148.

20. Ishikawa, Kaoru, (1989). Introduction to Quality Control. Productivity Press

21. Imai, Masaaki, (1991). Kaizen. McGraw Hill Book Company

22. Jacquemont, D., (2014). The Lean Management Enterprise: A system for daily progress, meaningful purpose, and lasting value by McKinsey and Company, 1164.

23. Jasti, N.V.K., \& Kodali, R. (2014). Validity and reliability of lean enterprise frameworks in Indian manufacturing industry. International Journal of Lean Six Sigma, 5(4), 361-391.

24. Jasti, N.V.K., \& Kodali, R. (2016). An empirical study for implementation of lean principles in Indian manufacturing industry. Benchmarking: An International Journal, 23(1), 183-207.

25. Kalton, Graham. (1983). Introduction to survey sampling. Sage Publications. 
26. Khadse, P.B., Sarode, A.D., \& Vasu, R. (2013, September). Lean manufacturing in Indian industries a review. International Journal of Latest Trends in Engineering and Technology, 3(1), 175-181.

27. Krishnan, V., \& Parveen, C.M. (2013, July 3-5). Comparative Study of Lean Manufacturing Tools Used in Manufacturing Firms and Service Sector. Proceedings of the World Congress on Engineering, London, UK., 1. ISBN: 978988-19251-0-7

28. Kumar, A. (2014). A Qualitative Study on the Barriers of Lean Manufacturing Implementation: An Indian Context (Delhi NCR Region). The International Journal of Engineering and Science (IJES), 3(4), 21-28.

29. Kumar, N., Kumar, S., Haleem, A., \& Gahlot, P. (2013). Implementing lean manufacturing system: ISM approach. Journal of Industrial Engineering and Management, 6(4), 996-1012.

30. Kume, Hitoshi, (1995). Management by Quality. Productivity Press.

31. Kundu G. K., \& Bairi, J. (2014). A scale for measuring the applicability of lean practices in IT support services. Journal of Enterprise Information Management, 27(5), 623-643.

32. Giunipero, Larry C, Kishore Gopalakrishna Pillai, Stephen N. Chapman, Ronald A. Clark, (2005). A longitudinal examination of JIT purchasing practices. The International Journal of Logistics Management, Vol. 16 Issue: 1, pp.51-70

33. Leong, Elaine K.F., Michael T. Ewing, Leyland F. Pitt, (2003). Australian marketing managers' perceptions of the Internet: A quasi-longitudinal perspective. European Journal of Marketing, Vol. 37, Issue: 3/4, pp.554-571

34. Liker, K.J., (2004, January 01). The Toyota way. New York, NY: McGraw Hill Education. ISBN-10: 0071392319

35. Lysonski, Steven, Srinivas Durvasula, John Watson, (2003) "Should marketing managers be concerned about attitudes towards marketing and consumerism in New Zealand? A longitudinal view", European Journal of Marketing, Vol. 37 Issue: $3 / 4$, pp.385-406

36. Mahapatra, S.S., \& Mohanty, S.R. (2007, January). Lean manufacturing in continuous process industry: An empirical study. Journal of Scientific Research, $66,19-27$.

37. Markku Kuula, Antero Putkiranta, Jarmo Toivanen, (2014). Effect of change - a longitudinal study into the changing manufacturing structures. Benchmarking: An International Journal, Vol. 21 Issue: 3, pp.329-343

38. Mathew, S.K., \& Jones, R. (2012). Toyotism and Brahminism: Employee relations difficulties in establishing lean manufacturing in India. Employee Relations, 35(2), 200-221.

39. Mishrikoti, A.H., \& Puranik, V.S. (2011, January-June). Implementation of LEAN Manufacturing in Small Scale Industry- Issues and Expectations. International Journal of Industrial Engineering Practice, 3(1), 9-13.

40. MIT (2012). LAI LESAT Data Entry and assessment tool, EXCEL File, Version 2.0 .

41. MIT (2012, February). LAI LESAT Facilitator's Guide, Version 2.0.

42. MIT (2012, February). LAI LESAT self-assessment tool, Version 2.0. 
43. Mohammad Ali Maasouman, Kudret Demirli. (2015). Assessment of Lean Maturity Level in Manufacturing Cells. IFAC-PapersOnLine, Volume 48, Issue 3, 2015, pp 1876-1881

44. Nesensohn, Claus; Bryde, David; Ochieng, Edward; Fearon, Damian. (2014). Maturity and Maturity Models in Lean Construction.

Australasian Journal of Construction Economics \& Building. 2014, Vol. 14, Issue 1, pp 45-59

45. Nightingale, Deborah J. and Joe H. Mize, (2002). 'Development of a Lean Enterprise Transformation Maturity Model'. Information Knowledge Systems Management, Vol 3, pp 15-30

46. Panwar, A., Jain, R., \& Rathore, A.P.S. (2015). Lean implementation in Indian process industries - some empirical evidence. Journal of Manufacturing Technology Management, 26(1), 131-160.

47. Prashar, A. (2014). Redesigning an assembly line through Lean-Kaizen: an Indian case. The TQM Journal, 26(5), 475-498.

48. Rajenthirakumar, D., Mohanram, P.V., \& Harikarthik, S.G. (2011, June). Process Cycle Efficiency Improvement Through Lean: A Case Study. International Journal of Lean Thinking, 2(1), 46-58.

49. Roy, R.N., \& Guin, K.K. (1999). A proposed model of JIT purchasing in an integrated steel plant. International Journal of Production Economics, 59(1-3), 179-187.

50. S. Vinodh, K.R. Arvind, M. Somanaathan, (2010). Application of value stream mapping in an Indian camshaft manufacturing organization. Journal of Manufacturing Technology Management, Vol. 21 Issue: 7, pp.888-900.

51. Sameh Mohamed Fahmi and Tamer Mohamed Abdelwahab, (2012). Case Study: Improving Production Planning in Steel Industry in Light of Lean Principles, Proceedings of the 2012 International Conference on Industrial Engineering and Operations Management, Istanbul, Turkey, July 3 - 6, 2012, pp 2489 - 2497

52. Sangwan, K.S., Bhamu, J., \& Mehta, D. (2014). Development of lean manufacturing implementation drivers for Indian ceramic industry. International Journal of Productivity and Performance Management, 63(5), 569-587.

53. Schlesselman, James J. 1973. Planning a longitudinal study: i. Sample size determination. J Chron Dis 1973, Vol. 26, pp. 553-560. Pergamon Press. Printed in Great Britain.

54. Seth, D., \& Gupta, V. (2005). Application of value stream mapping for lean operations and cycle time reduction: an Indian case study. Production Planning \& Control, 16(1), 44-59.

55. Shah, R. and Ward, P.T. (2003). Lean manufacturing: context, practice bundles, and performance, Journal of Operations Management, Vol. 21, pp 129-149.

56. Shah, R. and Ward, P.T. (2007). Defining and developing measures of lean production, Journal of Operations Management, Vol. 25, Issue 4, pp 785-805.

57. Shang, Gao and Low Sui Pheng. (2012). The adoption of Toyota Way principles in large Chinese construction firms. Journal of Technology Management in China, Vol. 7, Issue: 3, pp.291-316

58. Sharma, M., \& Gupta, S. (2015, March 23-25). Validity and Reliability of Existing Lean Service Frameworks in Indian Services. International Conference on Technology and Business Management, 307-313. 
59. Sharma, V., Dixit, A.R., \& Qadri, M.A. (2015). Impact of lean practices on performance measures in context to Indian machine tool industry. Journal of Manufacturing Technology Management, 26(8), 1218-1242.

60. Singh M.P., Meena, R., \& Panwar, A. (2016, May-August). A Survey on the Adoption of Lean Practices in Indian Manufacturing Sector. International Journal of Industrial Engineering Research and Development (IJIERD), 7(2), 52-62.

61. Singh, B. (2016). Identification of Lean Implementation Hurdles in Indian Industries. World Academy of Science, Engineering and Technology, International Journal of Behavioural Economic, Business and Industrial Engineering, 10(1), 1516-1520.

62. Singh, S., Atre, A.R., Vardia, A., \& Sebastian, B. (2014 a). Lean machine manufacturing at Munjal Showa limited. International Journal of Productivity and Performance Management, 63(5), 644-664.

63. Singh, R., Chopra, A., \& Kalra, P. (2014, b). Value stream mapping as a tool to identify the opportunities of lean techniques: an auto industry case study. International Journal of Science and Research, Vol 3, Issue 1, pp 1829-1833.

64. Smith, Steve, (2000). The quality revolution. Jaico Publishing House.

65. Spear, S., \& Bowen, H.K. (1999, September-October). Decoding the DNA of the Toyota Production System. Harvard Business Review 77, 5, 96-106.

66. Steffie van Schoten, Carolien de Blok, Peter Spreeuwenberg, Peter Groenewegen, Cordula Wagner, (2016). The EFQM Model as a framework for total quality management in healthcare: Results of a longitudinal quantitative study. International Journal of Operations \& Production Management, Vol. 36, Issue: 8, pp.901-922

67. Thanki, S.J., \& Thakkar, J. (2014). Status of lean manufacturing practices in Indian industries and government initiatives: A pilot study. Journal of Manufacturing Technology Management, 25(5), 655-675.

68. Upadhye, N., Deshmukh, S. G., \& Garg, S. (2010a). Lean manufacturing in biscuit manufacturing plant: a case. International Journal of Advanced Operations Management, 2(1-2), pp.108-139.

69. Upadhye, N., Deshmukh, S. G., \& Garg, S. (2010b). Lean manufacturing system for medium size manufacturing enterprises: an Indian case. International Journal of Management Science and Engineering Management, 5(5), 362-375.

70. Urban, Wieslaw, (2015). 20th International Scientific Conference Economics and Management - 2015 (ICEM-2015). The Lean Management Maturity SelfAssessment Tool Based on Organizational Culture Diagnosis. Procedia - Social and Behavioral Sciences, pp $728-733$

71. Van De Geer, John P. (1993). Multivariate analysis of categorical data: applications. Advanced Quantitative Techniques in the Social Sciences 3. Sage Publications.

72. Vinodh, S., Selvaraj, T., Kumar, S.C., \& Vimal KEK (2015). Development of value stream map for an Indian automotive component manufacturing organization. Journal of Engineering, Design and Technology, 13(3), 380-399

73. Wan, Hung-da \& F. Frank Chen. (2008). A leanness measure of manufacturing systems for quantifying impacts of lean initiatives. International Journal of Production Research, Vol. 46, No. 23, 1 December 2008, pp 6567-6584 
74. Womack, J.P., \& Jones, D.T. (2003, July). Lean Thinking: Banish Waste and Create Wealth in Your Corporation. London, U.K.: Simon \& Schuster UK. ISBN: 9780743231640.

75. Womack, J.P., Jones, D.T., \& Roos, D. (2007, July). The Machine that Changed the World, 19-69, London, U.K.: Simon \& Schuster UK. ISBN: 9781847370556.

76. Yadav, O.P., Nepal, B., Goel, P.S., Jain, R., \& Mohanty, R.P. (2010, May). Insights and learnings from lean manufacturing implementation practices. International Journal of Services and Operations Management, 6(4), 399-422.

77. Yogesh, M., \& Prabagaran, S. (2016). Study on Implementation of Lean Manufacturing Tools and Techniques. International Journal Applied Engineering Research, 1(5), 3289-3293.

\section{About Our Author}

Rajagopalan Jayaraman was educated at IIT Bombay in Metallurgical Engineering, IIM Ahmedabad and University of British Columbia where he graduated with Distinction in Metallurgical Engineering (MS), as also a Diploma in Production Management from the SIES Institute of Management, Mr. R Jayaraman has had an illustrious career spanning over 35 years. Starting with Mukand Iron and Steel Limited where he worked in production, design and R \& D of a steel plant, he went on to successfully install and commission the non-ferrous bi-metal sintering line for the manufacture of automotive bearings in Gabriel India Limited. He played a key role in the acquisition and merger of Special Steels and Ahmedabad Advance Mills with Tata Steel. He worked in the highest offices in Tata Steel - EA to the VC, Executive Officer to the MD Dr JJ Irani, head of Selection of a Coastal site for a 10 mtpa steel plant of Tata Steel, Chief of Project Planning, Monitoring and Cost Control of the world class 1.2 million tpa Cold Rolling mill project of Tata Steel which set several world records in project management and cost Rs 2,000 crores. He has also served as the Chief of Business Excellence of Tata Steel and Tata Communications Limited, both global giants in their respective areas of operations. He also worked as Senior VP of Technology and Chief Safety Officer of Tata Teleservices where he introduced industry standard practices in telecom tower management. He has co-authored, with the past Vice Chairman of Tata Steel, a well acclaimed book on project management. He has also authored more than 60 technical and management papers in various national and international journals some of which have won awards. He was selected by the "Best Citizens of India "forum and the "India International Friendship Society "for the "Best Citizen of India "and "Bharat Jyoti "awards for his services to academia and industry in 2013. He was also nominated by Tata Communications Limited for the "Best Change-maker "in the telecom industry in India in 2008. His current research interests are in inventory management, supply chain, operations planning, lean management and operations strategy. 